\title{
A velha arte de governar: o Conselho de Estado no Brasil Imperial
}

\section{The old art of governing: The Brazilian Imperial State Council}

\section{Maria Fernanda Vieira Martins}

\begin{abstract}
A instituição era admirável, e quando tudo (exceto a dinastia) se tinha vulgarizado, o Conselho de Estado, antes de vulgarizar-se, também, guardou por muito tempo o sabor, o prestígio de um velho Conselho áulico conservado no meio da nova estrutura democrática, depositário dos antigos segredos de estado, da velha arte de governar, preciosa herança do regime colonial, que se devia gastar pouco a pouco. Joaquim Nabuco
\end{abstract}

Indiscutivelmente os princípios norteadores do Estado imperial brasileiro eram, na feliz expressão de Francisco de Paula Sousa, monarquia e liberdade. Esse era o caminho da civilização. Se monarquia sem liberdade era escravidão, o caminho da liberdade para a monarquia em um país escravista era a Lei. Impregnados do sentimento de repulsa ao modelo das monarquias absolutistas que se generalizara entre letrados após as revoltas liberais européias - que parecia ameaçar também o trono brasileiro na figura de Dom Pedro I — a elite dirigente no país abraçou avidamente a causa da monarquia constitucional ${ }^{1}$.

No Brasil adotou-se um ideário europeu pós-revolucionário que havia se esmerado em marcar a ruptura com o Antigo Regime, identificando o absolutismo ao despotismo e negando qualquer continuidade entre estes e o novo modelo político-administrativo que então se instalava. Mas nem a monarquia absolutista européia foi necessariamente despótica, nem a monarquia constitucional reviveria no século XIX totalmente livre dos 
resquícios do Antigo Regime. A experiência brasileira demonstraria a força dessa tradição ao seguir, em grande medida, a forma como se organizou e se consolidou a monarquia portuguesa e seu modelo de administração.

Tanto a transferência da Corte portuguesa quanto o processo de Independência de 1822, acompanhado da opção pelo constitucionalismo, representaram marcos irrefutáveis na história política brasileira, no sentido de que nesse momento se iniciou a formalização das instituições que integraram a monarquia no país e que, entre avanços e recuos, seguiria o modelo europeu do estado-nação. Mas não se tratava da simples importação de um modelo. A compreensão dessa história não deve excluir a dinâmica da vida político-administrativa colonial, suas relações com a metrópole portuguesa e as práticas e ideais da elite que vivenciou e deu forma a esse processo.

$\mathrm{Na}$ construção da identidade do Estado Imperial brasileiro, o Conselho de Estado assumiu um papel central. A instituição havia sido criada oficialmente logo após a Independência e confirmada pela Carta constitucional de 1824. Seguia o modelo dos velhos conselhos áulicos europeus, com membros vitalícios, sofrendo a influência de uma prática político-administrativa tradicionalmente associada ao regime monárquico no velho continente. O primeiro Conselho atuou junto ao imperador Pedro I desde 1823, sobrevivendo à sua abdicação em 1831. Extinto no conjunto das medidas de caráter liberal presentes na reforma constitucional de 1834, foi restabelecido em 1841 como expressão dos esforços de reforma e pacificação do país e manutenção da ordem pública após os conturbados anos das regências.

A idéia de trazer de volta o Conselho de Estado à cena política surgiu em 1840. Em princípio, o momento não poderia ser mais propício, uma vez que, após o período regencial, vivia-se o retorno do imperador com a Maioridade, retorno este que ainda trazia consigo o Poder Moderador uma prerrogativa constitucional na vigência da Carta de 1824 — e a própria responsabilidade de se reconstruir a estrutura política e administrativa do Estado brasileiro. Ao longo de todo o II Reinado, o Conselho resistiu, juntamente com o Senado, como a mais estável e sólida das instituições monárquicas. Sua atuação política sempre excedeu suas atribuições originais e foi suprimido apenas com o desaparecimento da própria monarquia, cuja existência acompanhou e cuja ação procurou regular e controlar. 
Embora o Poder Moderador houvesse sido mantido pelo mesmo Ato Adicional que extinguira o primeiro Conselho de Estado, ambos se mantiveram unidos um ao outro. Indiretamente, o Conselho sempre esteve ligado à idéia de que representava uma saída conciliatória à aceitação do poder pessoal do monarca em uma sociedade política que, mesmo que moderadamente, não ousava desprezar os preceitos liberais que imperavam no cenário internacional.

Nesse contexto a ação empreendida pelas elites, baseada na necessidade de adequação do país ao sistema monárquico constitucional, implicava a superação de antigas práticas herdadas do período colonial. Tais esforços de conciliação não puderam prescindir da existência de instituições como o Poder Moderador - cuja atuação se materializava no Conselho de Estado - , que no Brasil assumiu a função arbitral reservada ao Estado pela cultura política do Antigo Regime, ou seja, um modelo que se pretendia liberal, que adotou o princípio montesquiano do equilíbrio entre os poderes, mas que esbarrou nos entraves representados pela tradição político-administrativa portuguesa ${ }^{2}$.

Tratava-se, assim, da vertente do pensamento liberal europeu que, entre outros aspectos, centrava na lei o limite da liberdade política. Com base na filosofia de Montesquieu, esta vertente encontrou seu desenvolvimento nas teses de Benjamin Constant — o principal mentor da geração de políticos brasileiros que então chegava ao poder —, que acrescentou ainda à teoria dos Poderes a idéia da neutralidade do poder da monarquia constitucional, justificando a criação do que no Brasil se denominou Poder Moderador.

Assim, o estudo sobre o Conselho, como instância de relacionamento entre o Estado e as elites, assume inegável importância, uma vez que o órgão traduziu, por um lado, o pensamento do Governo, por outro, sua adequação aos interesses dos grupos dirigentes e das elites ali presentes, permitindo observar como se davam as relaçôes entre os grupos dominantes e compreender os espaços e os limites que se colocavam para a execução de seus princípios e projetos para o país ${ }^{3}$.

Em geral, as assembléias de notáveis, e mesmo a idéia de conselhos políticos e administrativos, já bastante antigas em diversos países da velha Europa, foram organismos constituídos exatamente com a função de auxiliar a monarquia a exercer o papel de árbitro de conflitos e conciliação 
de interesses, funcionando como estruturas que facilitavam o exercício do poder ao negociar e intermediar as relações da Coroa com os diversos grupos políticos, particularmente com as autoridades regionais/locais. Assim, devem ser entendidas como instituiçôes ligadas diretamente ao poder central, em geral com ampla autonomia política e extensa ação reguladora e normativa e como lócus por excelência de redes políticas e sociais que concediam representatividade ao Estado e legitimavam suas ações ${ }^{4}$.

Fundamental ao entendimento desse processo, portanto, torna-se a identificação das redes de sociabilidade e parentesco que se pode observar a partir das elites reunidas no Conselho de Estado e suas relações de continuidade no que se refere aos principais grupos econômicos do país — os grandes negociantes e proprietários de terras e escravos - e às oligarquias regionais, as antigas famílias que, desde o período colonial, controlavam os poderes locais e estendiam sua esfera de influência não só para além dos próprios limites provinciais, como em direção ao poder central ${ }^{5}$.

Nesse contexto o capital e poder político de um indivíduo correspondiam não apenas ao seu status, mas ainda à sua capacidade de oferecer e retribuir benefícios, em um amplo esquema de trocas cuja função estruturante, no entanto, verificava-se em um nível mais cotidiano das relaçôes de poder. Na prática consistiam em aspectos informais a conviver com as estruturas formais de ordenação política e social, como as instituições ou a própria Justiça, transformando-se progressivamente em práticas marginais na proporção em que se complexificava o aparelho de controle e administração do Estado ${ }^{6}$.

Dessa forma, as práticas clientelares e as redes que estas alimentaram exerceram papel fundamental no próprio processo de centralização. Como poderes paralelos, poderiam funcionar como obstáculos à expansão do poder real mas, paradoxalmente, uma vez controlados, abriam caminho para um maior domínio da política e para o próprio reforço da unidade central. Em Portugal as redes familiares e institucionais começaram a perder sua força a partir da legislação pombalina em fins do século XVIII, basicamente ao transformar-se o caráter patrimonial das mercês em simples graça honorífica. Entretanto, embora deixassem de ser a norma, tanto em Portugal quanto no Brasil tais práticas não desapareceram instantaneamente, mas adaptaram-se às novas estruturas da política e do próprio Estado - considerando-se o aprimoramento dos processos eleitorais, a 
especialização institucional, a proliferação de cargos etc. —, mantendo-se ainda por tempo considerável no universo cultural da política luso-brasileira ${ }^{7}$.

Tratava-se de uma persistente cultura política que seguia ignorando as fronteiras regionais e reforçava uma prática de governo e dominação que resistia à propaganda e ao ideário liberais. As relações que essas redes retratam mostram uma realidade heterogênea, ambígua e dinâmica, espelhando as tensões características dos grupos e indivíduos nela envolvidos, considerando-se uma estrutura social na qual a própria identidade individual ainda se encontrava fortemente vinculada a relações familiares e redes sociais às quais estavam associados, o que fazia com que, com freqüência, antes de homens públicos, fossem representantes dos interesses e negócios dos grupos e famílias que os aproximaram do poder. A noção de rede complementa a compreensão do sentido que assume o termo elite pela consideração de que formam grupos com identidades construídas a partir de suas relações, crenças e práticas políticas ${ }^{8}$.

Portanto, para que o Conselho de Estado seja considerado como instrumento para a análise da ação e do comportamento das elites, trazendo um novo entendimento sobre o seu papel na política e na própria formação do Estado brasileiro, é preciso ampliar a abordagem no sentido de entender essas elites não como a representação de um grupo isolado, a partir de suas características internas de formação e composição, mas considerando ainda suas relações com a sociedade, através das redes de alianças e interesses que se constróem e se refazem permanentemente ao seu redor.

\section{Um pouco de homens, outro pouco de instituição: composição, trajetórias e redes}

À primeira vista os conselheiros de Estado no Segundo Reinado formavam um conjunto eclético, mas com diversos elementos unificadores. Em um primeiro panorama verifica-se que foram ministros, deputados, senadores, fazendeiros, negociantes, capitalistas, militares, militantes, jornalistas, homens de ciência, magistrados... Eram, em geral, descendentes de antigas famílias que controlavam a política, os cargos administrativos e as atividades econômicas no país já no período colonial, netos e bisnetos da antiga nobreza da terra ou de portugueses que aqui se uniram a famílias de origens paulistas, baianas e fluminenses, que na maior parte dos casos 
se deslocaram para Minas Gerais nos áureos tempos do ouro. Unia-os, indiscutivelmente, um passado de elite, uma experiência comum, e de seus antepassados pareciam haver herdado a velha arte de governar. Uniu-os ainda sua formação e ação política, de forma que até alcançarem o Conselho de Estado e os altos postos da administração imperial seguiram uma trajetória tumultuada, acompanhando cotidianamente os destinos do país.

A nomeação para o Conselho de Estado levava em conta o poder e a influência política, social e econômica desses atores, denunciada por suas próprias origens e trajetórias pessoais e por suas relaçóes sociais e políticas. No que se refere às suas origens, nota-se a concentração nas regiôes tradicionalmente reconhecidas como as mais dinâmicas do país - Rio de Janeiro, Bahia, Minas Gerais, São Paulo e Pernambuco —, em função do poderio econômico, social, demográfico e político, dada a importância das famílias oriundas dessas províncias.

A análise da composição do Conselho de Estado demonstra que o grupo manteve-se fortemente vinculado às bases locais que sediavam suas redes familiares e clientelares, o que denota uma conexão permanente com a própria política provincial, relações estas que ajudaram a ampliar e reproduzir na medida em que estabeleciam novos laços ou reforçavam antigas alianças estratégicas em outras regiôes. Pode-se observar alguma circulação em cargos jurídicos no início de suas carreiras, mas em cargos eletivos, aqueles em que era necessária uma base eleitoral local, como o Senado e a Câmara de Deputados, quase sempre representaram suas próprias províncias ou suas províncias de atuação, aquelas onde encontravam o apoio de suas redes de relacionamentos. Assim, através de suas trajetórias, seguindo conjunturas específicas, alimentavam e refaziam as complexas ligações parentais, sociais e clientelares que mantinham e reproduziam o poderio de suas famílias.

Nesse sentido, observa-se que, no que concerne aos 54 conselheiros que eram também senadores, 43 ou $80 \%$ elegeram-se por suas províncias de nascimento ou de atuação; dos 11 conselheiros que haviam representado outras províncias, três eram militares de carreira e dois tinham nacionalidade portuguesa. $\mathrm{O}$ mesmo se pode afirmar em relação aos 62 conselheiros que foram deputados, dos quais 47 ou $75 \%$ representaram suas províncias. Nesses casos, freqüentemente já possuíam uma carreira sólida na região, como vereadores ou deputados provinciais, vice-presidentes, juízes, inspetores do Tesouro etc. ${ }^{9}$ 
A nomeação para o Conselho parecia extremamente cuidadosa, pois se tornava óbvia a preocupação em manter um equilíbrio, mesmo que precário, entre os principais grupos que atuavam no cenário político. $\mathrm{O}$ elevado número de políticos para os quais não se pode identificar a filiação, aliado àqueles que publicamente assumiram uma posição apartidária e aos eternos adeptos da idéia da Conciliação, que sempre evitaram assumir posições radicais, fossem conservadores ou liberais, corroborava a tendência moderada no interior da instituiçãa ${ }^{10}$. Mesmo considerando-se a instituição ao longo de sua existência, observa-se que, na prática, a política partidária no interior do Conselho não diferia da forma como ela se desenvolvia fora dele, de modo que seus membros, em geral, eram designados para ocupar o cargo de acordo com a conjuntura ${ }^{11}$.

Assim, em diversos sentidos confirmava-se o discurso da necessidade da busca do equilíbrio, fundamental ao bom desenvolvimento da politica, bem como a idéia de que a instituição monárquica - na figura do imperador - e os órgãos supremos da organização política governamental deveriam manter-se acima das paixões. Essa postura, teoricamente, reforçava a idéia da imparcialidade que deveria ser inerente à monarquia, um antigo ideal que já vinha caracterizando o pensamento político brasileiro desde os primórdios do regime constitucional, do qual era testemunho a própria adoção do Poder Moderador, e que patrocinaria o espírito da Conciliação, perseguido tão habilmente pelo Marquês de Paraná na década de $1850^{12}$.

Quanto à principal área de atuação dos conselheiros, pode-se observar que o Conselho de Estado configurava-se indiscutivelmente como uma instituição que priorizava a ação política. Quase todos os conselheiros possuíam uma trajetória ligada à máquina administrativa do Estado, quer como conseqüência de uma formação de nível superior em Direito, como a ocupação dos cargos de juízes e magistrados, quer simplesmente devido a uma vida profissional que lhes permitiu chegar à Corte como membros do Senado, da Assembléia ou do Conselho de Ministros, passando muitas vezes por funções administrativas e legislativas locais, como deputados ou presidentes de províncias. Considerando-se a importância deliberativa dessas instituiçôes, pode-se afirmar que o Conselho de Estado reuniu os mais importantes representantes da política imperial, aqueles que possuíam o poder da tomada de decisóes como membros do alto escalão da administração pública. 
A ocupação de cargos técnicos ligados diretamente às atividades da Fazenda Nacional e provincial e à área financeira também era freqüente e demonstra que o controle que possuíam da vida política estendia-se amplamente também pela área econômica. $\mathrm{Na}$ esfera privada pode-se citar a participação dos conselheiros em algumas empresas e empreendimentos desde os primórdios de suas carreiras, participaçóes essas que, em diversos casos, se manteriam e multiplicariam nos anos seguintes. Acumulando simultaneamente cargos e funçôes, suas trajetórias traduzem as intrincadas inter-relações entre o político e o econômico, entre o público e o privado, demonstrando seu poder de interferência, controle e decisão sobre os destinos do país para além da política de Estado.

As experiências acumuladas e as trajetórias compartilhadas, algumas vezes na mesma tribuna, outras em campos opostos, assinalaram encontros e desencontros e indiretamente os prepararam para o exercício do poder. Nesse sentido, a tendência moderada que se verifica tanto na composição quanto nas próprias ações da instituição — solidamente embasadas no discurso da imparcialidade da administração imperial quanto aos partidos - não reflete o distanciamento do grupo em relação aos conflitos ou às principais questôes que ameaçavam a sociedade imperial brasileira. Ao contrário, traduz os embates e esforços de controle do ritmo das reformas e da manutenção da ordem hierárquica e governabilidade. Seus mecanismos de ação extrapolavam a questão partidária, ligando-se a filiações que os relacionavam diretamente aos interesses que representavam, particularmente os laços históricos com suas províncias e suas redes.

De fato, quando se considera os membros do Conselho de Estado verifica-se que integravam diferentes redes de relacionamentos que se perpetuavam e reconstruíam no país desde o século XVIII. Evidencia-se também a extensão do controle por elas exercido a partir das atividades econômicas e do aparato político-administrativo colonial, que incluía cargos "militares-administrativos" tanto quanto cargos jurídicos, cuja posse já era um indicativo da importância de seus detentores - como capitães-mores, ouvidores, senadores, magistrados, negociantes e proprietários de lavras auríferas, terras e engenhos. Essa cultura, essa forma de atuar da elite colonial perpetuou-se no período imperial, com a reconstrução, manutenção e reorientação das estratégias de alianças, conforme as diferentes 
conjunturas. Essas estreitas relações são ainda reveladas na continuidade dos laços matrimoniais e relações de parentesco e compadrio, que uniam o grupo a diversos setores dominantes, seja no nível local ou em uma rede mais ampla.

As instituições formais e informais da elite brasileira reforçavam essas relaçōes, servindo como espaços privilegiados de debate e produção intelectual. A convivência nos salóes da moda, nos grandes eventos sociais, nos bancos escolares, nos órgãos da administração, nas diretorias de empresas públicas e privadas aproximava naturalmente o grupo. Tal processo de integração tinha continuidade nas Faculdades de Direito de Olinda, São Paulo ou Coimbra, uma formação acadêmica comum que lhes havia proporcionado uma identidade intelectual e cultural que complementava as relaçôes provenientes de uma origem ou convívio cada vez mais estreitos, intensificando os laços de amizade e parentesco que se desenvolveriam na vida profissional.

Portanto, a convivência social torna-se o ponto de partida para a análise dos diferentes laços que uniam o grupo. Quem tivesse a oportunidade de freqüentar a mansão do conselheiro Marquês de Abrantes no Flamengo, em uma das famosas ocasiōes em que abria seus elegantes salóes à alta sociedade da Corte, teria certamente a chance de conhecer diversos personagens e de ali inteirar-se de suas histórias e relações pessoais. Se dispusesse de mais tempo e se a fortuna lhe sorrisse, graças a algum nível de indiscrição que sempre se apresenta em ocasiōes informais, poderia ainda obter informações realmente úteis, ao ouvir algo sobre os novos projetos do governo, sobre as ações do Banco do Brasil, sobre o afastamento de um desembargador da Relação, sobre o último pronunciamento do presidente do Conselho, sobre a falência de uma afamada Casa Comercial ou sobre detalhes da queda do ministério.

Certamente ali não lhe faltariam personagens para dar conta de tudo isso. Nos belos e iluminados salóes dos Abrantes, capitalistas, fazendeiros e homens de negócios, como o futuro Visconde de Mauá, encontrariam, para trocar idéias e impressões, diversos nomes do Conselho de Estado, como seu amigo pessoal, o Visconde do Rio Branco, José Maria da Silva Paranhos. O mesmo salão contava ainda com a presença do conselheiro Barão do Bom Retiro, Luiz P. do Couto Ferraz, um dos mais caros amigos 
de Sua Majestade, o Imperador Pedro II, mas que talvez preferisse evitar encontrar o Barão de Mesquita, Jerônimo José de Mesquita, a quem devia cerca de trinta e dois contos de réis. Mesquita, grande capitalista, proprietário e negociante, tinha larga intimidade com o meio financeiro, vocação e fortuna que herdara de seu pai, José Francisco de Mesquita, Conde de Bonfim. Apesar da dívida, no entanto, Bom Retiro e os Mesquita deviam ser antigos amigos, já que o Conde de Bonfim lhe deixara em testamento algumas de suas comendas. Bom Retiro parecia ainda particularmente ligado a outros importantes capitalistas, como o Visconde de Tocantins.

Nos intervalos dos jantares oferecidos aos amigos, em nome de sua longa amizade com o Barão do Rio Branco, Mesquita deixava de lado seus vultosos negócios, que faziam dele um dos homens mais ricos do país, para tratar pessoalmente dos parcos recursos que compunham o patrimônio da viúva do conselheiro Visconde do Rio Branco, aconselhando-a sobre a melhor forma de aplicar seus 28 contos de réis. Mas, em seu testamento, Mesquita contemplou apenas seus mais caros e próximos amigos, entre os quais o conselheiro Bom Retiro, o Visconde do Rio Bonito, vice-presidente do Banco do Brasil, e o já mencionado Tocantins, José Joaquim de Lima e Silva, irmão do conselheiro Duque de Caxias, ambos sobrinhos de outro conselheiro, o Visconde de Magé.

A família Lima e Silva estava ligada por casamento a outras grandes famílias da Corte, com origens em Minas Gerais e na própria província do Rio de Janeiro. Caxias era casado com uma neta do negociante Braz Carneiro Leão e era sogro de Francisco Carneiro Nogueira da Gama, Barão de Santa Mônica, proprietário na região de Vassouras em cuja fazenda faleceria anos depois. Seu irmão, Tocantins, casara-se primeiro com uma prima, filha do Marquês da Gávea, e depois com uma Souza Breves, família que incluía alguns dos mais importantes produtores de café no vale fluminense e que reuniria vultosas fortunas individuais.

Tanto os Carneiro Leão quanto os Nogueira da Gama, cuja família tinha como patriarca o Marquês de Baependi, ligavam-se a dois outros conselheiros, Honório Carneiro Leão, Marquês de Paraná, e seu genro e sobrinho Jerônimo Teixeira Júnior, Visconde do Cruzeiro, respectivamente sobrinho e neto do comerciante e capitalista Nicolau Netto Carneiro Leme. Companheiro de Paraná nos idos tempos de Coimbra e seu correligionário nas bancadas do Partido Conservador, o Marquês de Olinda pertencia 
à linhagem dos Cavalcanti de Pernambuco, assim como o conselheiro Visconde de Albuquerque. O filho de Olinda casou-se com Laura de Faro, filha de Antônio Pereira de Faro e Francisca Clemente Pinto, casamento que proporcionou a aproximação com a família dos barôes de Rio Bonito, com os paulistas Campos Vergueiro e com os Clemente Pinto, cujo patriarca era o abastado fazendeiro e capitalista Barão de Nova Friburgo.

O Conde de São Clemente, filho de Nova Friburgo, era amigo pessoal e antigo colega do Visconde do Cruzeiro na academia paulista. Cruzeiro, cujo pai havia sido sócio do Barão de Mauá, era capitalista e homem de vastos negócios. Como membro da comissão fiscal do Banco Rural e Hipotecário do Rio de Janeiro, conviveu diretamente com o poderoso capitalista José Machado Coelho de Castro, sogro de Mariano Procópio Ferreira Lage, primo-irmão do conselheiro Conde de Prados.

Uma das filhas de Cruzeiro tornou-se esposa do conselheiro Paulino Soares de Sousa, que no Conselho de Estado conviveria com seu primo Francisco Belisário, respectivamente filho e sobrinho do conselheiro Visconde de Uruguai, por sua vez amigo pessoal e concunhado de José J. Rodrigues Torres, Visconde de Itaboraí, que trabalhara no Tribunal do Tesouro com o conselheiro José Antônio da Silva Maia, responsável pelo testamento do conselheiro Bernardo Pereira de Vasconcelos, e de quem era testamenteiro o Barão de Uruguaiana, conselheiro Silva Ferraz. O irmão de Itaboraí, Barão de Itambi, que se encontrava na diretoria das principais companhias e instituições financeiras, casara sua filha com um Carneiro Leão, filho do Marquês de Paraná.

O Conde de Prados era cunhado de José Ribeiro de Rezende, Barão de Juiz de Fora, sobrinho de um membro do primeiro Conselho de Estado, Marquês de Valença, ligado por casamento a uma nobre família de São Paulo, os Souza Queiroz, parentes diretos do abastado fazendeiro, político e negociante paulista Rafael Tobias de Aguiar e de seus rebeldes de 1842, que mesmo em meio às intempéries da revolução havia encontrado tempo para legalizar sua ligação extra-conjugal com a marquesa de Santos, que já durava mais de dez anos e da qual havia já seis filhos, legitimados com o casamento dos pais. À mesma família pertencia o conselheiro Francisco de Paula Sousa e Melo, tio e sogro do Barão de Limeira, também Sousa Queiroz, cuja mãe se casara com um antigo regente, o conselheiro baiano Marquês de Monte Alegre, José da Costa Carvalho. 
Além do salão do Marquês de Abrantes, Monte Alegre era assíduo freqüentador do Cassino Fluminense, onde gostava de perder alguns tostões que por certo não lhe fariam falta, possivelmente parte daqueles que ganhara em sua sociedade em São Paulo com o Barão de Mauá, que ainda incluía o conselheiro Pimenta Bueno, Marquês de São Vicente. Lá encontrava ainda o Barão de Rio Bonito e o conselheiro Abrantes, que participavam ainda de outro animado salão, sustentado pelo conselheiro José Thomaz Nabuco de Araújo, onde deparava-se com o círculo de políticos pernambucanos que se reuniam em torno do anfitrião, especialmente o também conselheiro Visconde de Sinimbu - membro de uma família de senhores de engenho em Alagoas e Pernambuco e presidente do Banco Nacional de Depósitos e Descontos, amigo pessoal de Nabuco desde os tempos em que haviam estudado juntos em Recife. Encontrava ainda o Barão de Mauá, os conselheiros Manoel Pinto de Souza Dantas, o Visconde de Abaeté - cuja filha casara-se com o filho de outro conselheiro, o marechal João Paulo dos Santos Barreto - Olinda, Caxias, Rio Branco, Sapucaí, Bom Retiro, Torres Homem e Bernardo de Sousa Franco.

Sinimbu era amigo do Visconde de Figueiredo, por sua vez amigo e peça fundamental no saneamento das finanças empreendido pelo conselheiro Visconde de Ouro Preto, Affonso Celso de Assis Figueiredo; era também membro do chamado "ministério dos velhos", do qual ele, contando cinqüenta anos de idade, era o mais moço, e do qual também fazia parte o Marquês de Abrantes, retornando ao já mencionado proprietário de um dos mais elegantes salóes freqüentados pela elite carioca ${ }^{13}$.

Essa teia de relacionamentos variados - à qual deve-se acrescentar ainda o convívio, ao longo de suas trajetórias, nos quadros diretores de diversas instituiçóes científicas, irmandades religiosas, sociedades literárias e órgãos da imprensa - era ainda alimentada pela convivência nas diretorias e conselhos tanto dos órgãos da administração pública quanto dos bancos e empresas privadas. Entretanto, nesse ponto a análise deve extrapolar o sentido puramente social que lhe é inerente, de reiteração de laços de amizade, para abarcar ainda o sentido que apresentava a relação entre os homens de Estado e aqueles que detinham o poder econômico, entre as esferas pública e privada, entre a autoridade central e as diferentes províncias.

Portanto, além das relaçóes que se estabeleciam na Corte, onde se destacam as estreitas ligaçóes que uniam os conselheiros aos grandes comerciantes e capitalistas e ao que se poderia considerar uma incipiente 
elite empresarial, evidencia-se ainda como a alta cúpula do poder imperial reunida no Conselho de Estado encontrava-se próxima às oligarquias regionais, fosse por linhagem direta ou por uma eficiente política de casamentos. $\mathrm{Na}$ verdade, era nas principais províncias do Império brasileiro que muitas vezes se originavam e ramificavam as relaçôes pessoais e familiares verificadas na Corte, alimentadas pelas práticas clientelares e de poder e dependência pessoal, que davam sustentação eleitoral e política ao governo central. Assim, essas redes apresentavam-se multifacetadas e multidirecionadas, integrando indivíduos e representações de interesses diversos ao longo do II Reinado e espelhando diferentes e mutáveis estratégias de negociação para perpetuação do poder e manutenção do status.

\section{0 depositário das tradições: a ação político-administrativa do Conselho de Estado}

A instituição era acionada mediante avisos emitidos pelo Ministério dos Negócios do Império, referindo-se a consultas canalizadas pelos ministros e secretários de Estado, provenientes do próprio Executivo ou de outras instâncias administrativas, em especial dos presidentes das províncias ou de autoridades jurídicas locais. Estas eram, em princípio, direcionadas a uma das quatro seções organizadas no Conselho: Justiça e Estrangeiros, Império, Fazenda e Marinha e Guerra. As seções eram compostas por três conselheiros e presididas pelo ministro titular da pasta correspondente. Os membros das seções deveriam analisar a consulta e emitir um parecer que seria submetido pelo Executivo ao imperador para as devidas providências.

A grande maioria das consultas encaminhadas ao Conselho era decidida no âmbito da própria Seção, entretanto, aquelas que chegavam à reunião geral do conselho, com a presença da totalidade dos conselheiros em exercício, denominado Conselho Pleno, traziam a indicação seja ouvido o Conselho de Estado como resolução do imperador, de onde se deduz que diante da complexidade de determinados casos Pedro II e seus ministros preferiam submeter o parecer ao conjunto da instituição.

As reuniōes do Conselho Pleno eram convocadas por orientação direta do monarca sem uma periodicidade pré-estabelecida, sempre que este julgasse necessário apelar aos conhecimentos e ao apoio político que lhe pode- 
riam conceder seus conselheiros. Por outro lado, geralmente em função da urgência que demandavam, diversas consultas eram submetidas diretamente ao Conselho de Estado Pleno sem que antes tivessem sido analisadas pelas seções, em especial quando se tratavam de questôes de caráter sigiloso, quando se referiam à implementação de projetos e reformas propostos pelo próprio governo, crises e conflitos emergenciais entre os poderes etc. Após ouvir o Conselho, imperador e ministros, conforme o caso, reencaminhavam o parecer à Seção para sua adequação e incorporação das observaçôes surgidas no debate ou tomavam sua decisão e davam ao assunto o encaminhamento cabível, em geral a partir da publicação de um decreto ou de uma resolução imperial.

Entre março de 1842 e agosto de 1889 o Conselho de Estado Pleno realizou 270 conferências. A freqüência variável das conferências era explicável por fatores diversos e de naturezas variadas. As razóes para esse comportamento devem considerar aspectos como a conjuntura política e econômica geral do país, a necessidade premente de discussão de temas específicos, a composição partidária do gabinete ministerial e da Câmara dos Deputados e seu relacionamento com o Conselho.

Quanto aos primeiros anos, particularmente a primeira metade da década de 1840, a maior freqüência das reuniōes pode ser entendida em razão da necessidade de definição de competências e esclarecimentos gerais diante do caos gerado pelo amplo programa de reformas de teor jurídico-administrativo inerente ao próprio processo de fortalecimento da autoridade do Estado. De fato, tal processo vinha acompanhado de um ímpeto legislativo fundamental à organização administrativa, com sucessivas reformas que se sobrepunham umas às outras e que vinham se realizando desde a época regencial. Nesse momento, o Conselho começava a assumir o papel de órgão responsável pela inteligência da lei. Assumia, no entanto, extra-oficialmente, uma vez que tal atribuição não constava explicitamente em sua lei de criação, nem em seu regimento interno, elaborado em 1842.

Em geral, tratava-se de consultas que identificavam indefinições, omissões e a necessidade de esclarecimento de funções e competências administrativas, nos conflitos entre as autoridades provinciais e as prerrogativas do poder central em nomeações diversas, decisões judiciais, legislação provincial etc., decorrentes do empenho em se retirar das províncias o máxi- 
mo de poder, objetivando a consolidação do centralismo almejado pelos idealizadores do novo Império e defensores ardorosos da autoridade central. No que se referia a dúvidas quanto ao procedimento legal, encaminhadas por instâncias diversas da administração ou por juízes locais, em geral as seções identificavam falhas na legislação, apresentando em parecer a sugestão de elaboração de novas leis ou leis complementares. Nesses casos era comum a formação de comissões específicas, organizadas no âmbito do próprio Conselho, que se dedicariam, assim, à elaboração de projetos de lei ou regulamentação, a serem encaminhados à Assembléia Geral.

De fato, antecipando-se em oito anos à extinção do tráfico negreiro e às suas conseqüências sobre a questão da mão-de-obra e organização do trabalho, já em 1842 a Seção do Império apresentava um projeto de regulamentação de uma política de sesmarias e colonização estrangeira que resultaria na lei de terras aprovada em 1850. Após as discussões relativas a seu próprio regimento, portanto, o Conselho iniciava seus trabalhos discutindo duas importantes reformas, a questão da mão-de-obra e o regime de terras, e a legislação eleitoral, com proposta de reforma também elaborada na Seção do Império.

Outros exemplos quanto a reformas legislativas seriam, em 1851, o projeto para a execução e regulamentação da lei de terras; em 1856 o de casamentos mistos, que regularizava a união entre católicos e protestantes, medida então vista como essencial diante do afluxo de imigrantes ao país; em 1859, o de emissão bancária, que obrigava o Banco do Brasil e demais instituições financeiras autorizadas à emissão pelo Poder Executivo a realizar suas notas em ouro no prazo máximo de dois anos; em 1867 iniciou os trabalhos relativos ao projeto para abolição gradual da escravidão, ao mesmo tempo em que discutia projeto de criação de conselhos para as presidências das províncias; em 1874 elaborou projeto de regulamentação das concessões para construção de estradas de ferro acerca da garantia de juros e outros favores a empresas de viação férrea no Império, junto com outro de reforma eleitoral, e em 1880, a reforma da Lei de Terras.

Por outro lado, o Conselho apresentaria uma atividade profícua na própria organização e regulamentação da estrutura governamental e de serviços públicos. Ainda quanto a essa atividade reguladora, entre diversos assuntos, podem ser citados a proposta de reforma dos correios, em 1842; 
regulamento da polícia naval nos portos do Império, em 1842; projeto sobre aposentadorias, 1843; regulamento da alfândega, 1844; das missões de catequese e civilização dos índios, 1845; do registro geral de hipotecas, 1850; da lei sobre o serviço do exército e armada, 1875; projeto de lei para revisão e classificação das rendas gerais, provinciais e municipais do Império, 1883.

Quanto à origem das consultas que chegavam ao Conselho Pleno, cabe registrar que cerca de $33 \%$ das solicitaçôes foram encaminhadas diretamente pelo Poder Executivo. Entre estas destacam-se os pedidos de dissolução da Câmara dos Deputados, originados de conflitos "inegociáveis", ou que se diziam inegociáveis, entre o Gabinete e o Legislativo no que se referia à aprovação de projetos de lei, decretos e regulamentações, incluindo problemas estruturais, como reformas eleitorais, a questão servil e a questão de terras; conflitos internacionais, majoritariamente relativos à questão do tráfico de escravos e os embates com o governo britânico, as disputas na região do Prata na década de 1840 , além da própria guerra do Paraguai, e questôes de Fazenda, especialmente ligadas à política emissionária e à crise de 1864 .

Dentre as consultas submetidas ao Conselho Pleno cerca de 15\% referiram-se às prerrogativas do poder pessoal do monarca. Tal quadro pode ainda ser visto como uma amostra de como a política imperial utilizou-se do Moderador, destacando-se a ênfase em duas questôes-chave para o cenário nacional ao longo do Império, ou seja, o controle do Poder Legislativo, através da possibilidade de prorrogação, adiamento e dissolução da Câmara dos Deputados, e o controle da autonomia das províncias, que se refletia na possibilidade de questionar as leis das assembléias regionais.

Inquestionavelmente era no trabalho das seçôes do Conselho de Estado que se verificava com maior clareza a real atuação da instituição, uma vez que a maior parte das consultas encaminhadas à instituição encontrava sua solução nessa instância ${ }^{14}$. A Seção de Justiça poderia ser considerada a verdadeira responsável pela construção de uma unidade administrativa e jurídica no país. Funcionando, na prática, como uma instância superior, fixou os limites legais, definiu a compreensão da legislação, reformou-a quando julgou necessário, propôs novas leis e regulamentações. A Seção também serviu como árbitro em questões jurídico-administrativas que freqüentemente opunham as autoridades centrais às provinciais ou, como 
parecia mais comum, na administração dos conflitos entre as próprias autoridades provinciais. Tal atuação mostrou-se fundamental no que se referiu aos freqüentes impasses que envolveram o Legislativo, Judiciário e Executivo regionais diante da disputa permanente de poder, ao menos em meados do século, quando era maior a resistência de antigos poderes locais à influência reguladora e centralizadora dos presidentes de província e chefes de polícia nomeados pelo governo central. Juntamente com a Seção do Império, procurou fixar as atribuições dos cargos e autoridades provinciais e municipais, muitas vezes chocando-se frontalmente com os antigos Tribunais de Relação, onde se encastelavam os magistrados representantes dos poderes locais ${ }^{15}$.

Nos pareceres torna-se mais fácil observar os caminhos que seguiam os processos até alcançarem a Seção de Justiça que, em geral, funcionava como um último estágio para julgamento de recursos. Em princípio, o que deslocaria um determinado processo dos trâmites tradicionais do Judiciário para o âmbito do Conselho de Estado era sua caracterização como conflito de jurisdição. De fato, de acordo com o capítulo III do Regimento do Conselho, ficava estabelecido que era responsabilidade dos presidentes de província ou do procurador da Coroa no Rio de Janeiro investigar a atuação de autoridades judiciárias sobre objetos de teor administrativo e, no caso de se confirmar a improcedência, enviar a questão à secretaria de Justiça do Ministério da Justiça, caminho pelo qual chegaria ao Conselho.

Dessa forma o governo dava plena execução prática às prerrogativas centralizadoras da Justiça e administração pública concedidas por duas leis polêmicas, a própria lei de criação do Conselho de Estado, em 1841, e a reforma do código de processo criminal, em dezembro do mesmo ano, elaborada por um futuro conselheiro de Estado, Paulino J. Soares de Sousa, Visconde de Uruguai. Conhecida como Lei de Centralização da Justiça e da Polícia, vinha reformular o Código de Processo Criminal de 1832, votado no contexto das reformas de caráter descentralizador que marcaram o início do período regencial, uma legislação que concedia amplos poderes às autoridades locais. A nova lei, entre diversas determinaçóes, criava ou transformava em cargos nomeados pelo Poder Executivo antigos postos até então eletivos, além de esvaziar consideravelmente o papel e os poderes concedidos aos juízes de paz, que se mantinham como cargos eleitos. 
Assim, em função do destaque que concediam ao controle do que chamavam conflitos de jurisdição, o governo demonstrava todo seu ímpeto em manter sob rígida observação a máquina administrativa do Estado. Nesse processo, o Conselho de Estado, trabalhando sempre próximo ao Ministério da Justiça, assumia função fundamental para assegurar ao poder central o controle das instâncias locais, quando se considera ainda suas prerrogativas de análise da legislação provincial.

Quanto à Seção dos Negócios do Império, configurou-se como instância responsável pela organização, planejamento e desenvolvimento das ações políticas e econômicas do governo ao longo do período, em especial no que se referiu às discussões de regulamentação e fiscalização dos processos eleitorais e de reforma da legislação concernente a esse tema e àquelas relativas aos principais problemas enfrentados pela agricultura nacional. Por outro lado, as consultas que trazia ainda representaram um fundamental papel regulador das relações entre o poder central e as províncias, papel este que, em geral, dividiu com a Seção de Justiça ${ }^{16}$.

Segundo o relatório do Ministério dos Negócios da Agricultura, Comércio e Obras Públicas de 1864, a Seção do Império registrou, em 20 anos de funcionamento, entre 1842 e 1864, 831 consultas apenas no que se refere às questões que estariam sob a responsabilidade desse ministério após 1860, quando foi criado. Assim, esse total exclui todos os demais temas discutidos na Seção, particularmente as questôes eleitorais e as leis provinciais, que ocupavam uma parcela considerável dos debates. A ação reguladora do Conselho incluía ainda o controle da concessão de patentes e privilégios industriais, comerciais e de serviços, que se referiam a $28 \%$ do total de consultas submetidas. Entretanto, tal número seria infinitamente superior se fossem consideradas as concessões de privilégios e serviços específicos, que encontram-se ainda dispersas nos itens navegação, estradas de ferro, colonização, mineração e obras públicas, nos quais as consultas versavam majoritariamente sobre esse objeto. Também o item relativo ao comércio e sociedades anônimas registra um número elevado $(28,5 \%)$, onde predominavam as solicitações para aprovação e reforma de estatutos de companhias ${ }^{17}$.

Cabe ressaltar que a possibilidade de análise dessas consultas em particular permitia de forma mais direta o favorecimento de grupos específicos ou elementos integrantes das redes das quais faziam parte os conselheiros que, em uma atividade mais cotidiana, estariam mais livres para 
agir de acordo com seus interesses. Na prática, avaliavam as atividades de seus pares e, com freqüência, de seus próprios sócios, amigos e familiares.

O que se destaca na observação e análise das consultas submetidas é, em primeiro lugar, o volume e a amplitude dos temas ali debatidos. Algumas seções, ao menos em determinados períodos, chegaram a manter reuniões semanais e, freqüentemente, emitiram um número considerável de pareceres diários, em contraste com o ritmo dos trabalhos no Conselho pleno. Um outro aspecto refere-se à repercussão e à aplicabilidade das soluções indicadas nos pareceres, um primeiro sinal indicativo do papel da instituição na condução geral da política e administração imperial. Nesse sentido, ao menos quando se verifica o volume de decretos que se basearam em decisões do Conselho, considerado em conjunto com a freqüência com que o imperador registrava o Como Parece nos livros de pareceres das seçôes, parecem realmente indicar que, em geral, as soluçôes fornecidas pela instituição foram efetivamente seguidas pelo Poder Executivo ${ }^{18}$.

Entretanto, se os pareceres das seções eram usualmente aceitos a ponto de se transformarem em atos legislativos oficiais, cabe ressaltar que não era nessa instância que se decidiam as questóes mais emblemáticas e os temas mais polêmicos. Embora as consultas nas seções gerassem pareceres discordantes, as divergências surgiam mais claras nos votos emitidos no Conselho Pleno, onde as atas efetivamente registram o debate e onde se verifica que a votação dificilmente alcançava a unanimidade dos conselheiros presentes.

Assim, embora seja fundamental a análise da aceitação e a confirmação das deliberaçõos emitidas pela instituição, a avaliação do papel desempenhado pelo Conselho na política imperial deve ainda considerar a própria ausência de consenso expressa tanto nos pareceres das seções quanto nas votaçôes do Conselho Pleno. Naturalmente, questôes polêmicas como usualmente foram, por exemplo, a questão servil e os pedidos de dissolução da Câmara dos Deputados, sempre geraram discussóes acaloradas e a divisão dos votos na instituição, e as decisões tomadas a partir dessas consultas privilegiaram um ou outro dos argumentos ali presentes, de acordo com as conjunturas. Nesse sentido, o ato da consulta e o debate são mais significativos para a compreensão do papel da instituição do que a resolução final do monarca.

De fato, a política partidária, os debates, os conflitos, ali não estavam ausentes; ao contrário, davam ao Conselho o movimento e dinamismo 
que se esperaria de um organismo dessa natureza, que se encontrava no centro das decisões governamentais. Tais aspectos demonstravam sua legitimidade na representação de interesses tanto quanto seu profundo envolvimento com os temas mais caros à política, reafirmando ainda seu papel como espaço de negociação e administração de conflitos.

Nesse contexto, a questão administrativa configurava-se em um elemento fundamental. Como havia declarado Paulino Soares de Sousa, enunciando o discurso recorrente tanto entre liberais quanto conservadores, a política era o lugar das paixóes e a racionalidade ali ausente deveria ser obtida com a sua mais eficiente auxiliar. Nesse sentido, o Conselho de Estado se utilizou de suas prerrogativas legais e regimentais de forma a garantir a uniformidade da marcha administrativa no meio dos vaivéns da política $^{19}$. A administração deveria ser, então, o lugar da razão, porque representava ainda o império da lei. E efetivamente, malgrado as tendências partidárias e a filiação a interesses específicos, a instituição preocupava-se em manter e demonstrar essa face, procurando embasar os pareceres na legislação, fosse o Ato Adicional, os diversos códigos legais ou, principalmente, a Constituição.

Esse era, na verdade, um importante componente no ideário político imperial e talvez ele seja o principal responsável pela longevidade do Conselho de Estado, garantindo seu prestígio e impedindo sua vulgarização, mesmo quando se generalizava o clamor por uma feição mais democrática ao governo imperial, após a década de 1870 . No discurso que poderia ser considerado o discurso oficial, a velha arte de governar identificava-se com a preciosa herança colonial, nas palavras de Joaquim Nabuco, com a idéia da importância de um corpo de sábios letrados dedicados ao conhecimento da lei. Identificava-se, assim, com o desejo de manter a administração pública independente e autônoma, fazendo dela a responsável pela diluição dos conflitos, tão inerentes ao fazer política. Em diversos sentidos, a arte de bem governar relacionava-se ao controle das atividades normativas e regulamentares, da prática e dos ritos administrativos, e era esse controle que garantiria o sucesso da política imperial.

Entretanto, cabe reafirmar que, malgrado o discurso em prol da imparcialidade e da neutralidade, as elites representadas no Conselho, através da instituição, faziam cumprir as leis que elas mesmas elaboravam, interpretavam e defendiam. Os próprios princípios de sua ação encontra- 
vam sustentação em bases autoritárias, assim entendidas pelo seu caráter inibidor da representação, da autonomia provincial e da liberdade dos poderes constituídos. Essas bases eram principalmente as prerrogativas do Poder Moderador e as leis de criação do Conselho e de Reforma do Código Criminal, cujo caráter centralizador e autoritário não havia escapado à oposição, especialmente aos rebeldes de 1842. Com esses instrumentos davam execução a um projeto de organização político-administrativa que se mantinha excludente e que seguia adiando as reformas essenciais à sua modernização.

\section{Os excessos da centralização e as relações entre os poderes}

Uma das principais ações que envolveu as elites reunidas no Conselho de Estado dizia respeito, direta ou indiretamente, à consolidação de uma autoridade central, medida então vista como fundamental para a manutenção do regime constitucional. Tal questão passava, naturalmente, pelo controle do que se poderia compreender como os poderes paralelos exercidos em instâncias diversas da administração pública, sem, contudo, afetar as hierarquias sociais. Incluía, por conseqüência, a montagem de uma sólida estrutura administrativa, garantindo a absorção dos serviços básicos pelo poder público.

A questão incluía os esforços para convencer os poderes locais das vantagens na transferência dessa autoridade ao Estado. Nesse processo, a estratégia fundamental foi a negociação permanente com os diversos setores e interesses que envolviam os poderes locais, que também se beneficiavam da existência de uma autoridade central efetiva e legalmente constituída. Cabe destacar que, malgrado algumas resistências e fracassos de ambos os lados, tal processo foi por ambos buscado e desejado, inclusive dada a forte presença dos representantes dessas oligarquias no poder central ao longo de todo o período.

Entretanto, o governo viu-se, imediatamente após o Regresso diante de um poderoso obstáculo, representado pelo crescimento das autoridades locais em grande parte decorrente das disposições descentralizadoras do Ato Adicional de 1834. Assim, a primeira obra de seus negociadores, papel amplamente desempenhado pelo Conselho de Estado e a Presidên- 
cia das províncias, foi o refreamento do poder provincial, para o qual se utilizaria, mais uma vez, da lei como instrumento de coerção. Utilizou, portanto, três armas poderosas já anteriormente mencionadas, três leis controversas elaboradas entre 1840 e 1841 , que concediam amplos poderes ao governo sobre as províncias: a Lei de 12 de maio de 1840, interpretando e revendo alguns artigos da reforma da Constituição no que respeitava ao poder das assembléias provinciais; a lei de 23 de novembro de 1841, de criação do Conselho de Estado, que concedia a essa instituição o controle das leis promulgadas por essas assembléias; e a lei de 3 de dezembro de 1841, que dispunha sobre a organização do poder de justiça e polícia do Estado.

Portanto, a questão da centralização como controle dos poderes paralelos passava pelas assembléias provinciais, em especial pelo controle de suas leis, tema que ocupou a maior parte do trabalho das seções do Império e da Justiça. A análise dessas leis permitiu ao Conselho reforçar ainda mais a ação do poder central, uma vez que a atenção maior concedida a esse exame visava garantir que as assembléias provinciais se manteriam duplamente sob controle, impedidas de legislar fora do que então consideravam sua jurisdição e evitando-se que esta legislação viesse de encontro ou sobrepujasse às leis gerais do país.

Esse será um tema caro ao Conselho de Estado na década de 1840, quando se considera a freqüência com que sua análise era submetida ao Conselho Pleno. Na verdade, tal discussão envolvia um problema fundamental, que dizia respeito ao Poder Legislativo concedido às províncias pelo Ato Adicional de 1834 que, dependendo dos interesses e da interpretação, poderia estar em contradição com a prerrogativa constitucional concedida ao Poder Moderador. Essa atribuição ao Conselho estava prevista no seu regimento, que definia que cada Seção examinaria as leis provinciais e todos os negócios de que a encarregar o seu presidente. Teoricamente, a instituição seria acionada apenas nos casos em que se colocasse algum tipo de conflito entre a assembléia e o presidente da província, quando este não sancionasse as leis por ela aprovadas, embora se registrem diversas ocasiōes em que essas leis foram analisadas mesmo obtendo a aprovação do presidente.

Mas as dificuldades enfrentadas pelos sucessivos gabinetes em manter a autoridade sobre as províncias aumentavam progressivamente. A nego- 
ciação e as estratégias de aproximação e conciliação seriam então o verdadeiro espírito condutor da política regional. Nesse contexto, o presidente de província assumia um papel fundamental, apresentando-se como o principal intermediário e um fundamental agente de negociação, pela ligação que proporcionava entre poderes locais e governo central. Tal estratégia foi amplamente utilizada, motivo pelo qual a escolha daqueles que exerceriam essa função jamais seria inconseqüente, ao menos no que se relacionava às principais províncias do Império, obedecendo a uma rigorosa lógica de garantir o controle da situação. Indubitavelmente, no entanto, tratava-se de uma lógica conjuntural, no sentido de que era determinada pelo contexto político tanto da província quanto da Corte, pelo partido que se encontrava no poder e suas correlações de força.

Uma lógica conjuntural mas, enfim, uma lógica. A escolha era cuidadosa, pois a fidelidade ao projeto centralizador era essencial. Essa constatação justificaria, por exemplo, o envio de políticos importantes na Corte para as províncias, particularmente em momentos de conflito. Entre diversos casos, poderia ser citada a nomeação de Paraná para a Presidência de Pernambuco após a Revolução Praieira em 1849, ou a nomeação de Caxias para a província do Rio Grande do Sul em 1845, para consolidar a vitória sobre os farrapos, além da escolha de Monte Alegre para a província de São Paulo, no auge dos conflitos que geraram a revolução liberal de 1842. Além do papel desempenhado nas negociações, eram ainda os presidentes que tinham a missão fundamental de canalizar as demandas provinciais para o Executivo e para o próprio Conselho, denunciando os abusos de autoridade, os conflitos de jurisdição regional entre o Legislativo, Judiciário e Executivo, os desmandos dos poderes locais etc.

No entanto, o que parece mais importante é considerar que os poderes provinciais, em especial as assembléias, jamais se conformaram com a lei de interpretação do Ato Adicional que anulava alguns de seus dispositivos mais autonomistas, com as prerrogativas do Conselho de Estado em analisar a legislação provincial e muito menos com a lei de reforma do código, de forma que a eterna vigilância sobre as ações dessas câmaras gerava uma tensão permanente entre o governo e as assembléias e a política local. Essa situação impunha um enorme esforço de negociação cujo sucesso parecia cada vez mais incerto, uma vez que crescia a intolerância com as ações centralizadoras do Estado, que começavam a interferir no 
desenvolvimento da política provincial engessando seu desenvolvimento. Portanto, nem sempre a negociação e as tentativas de implementação de reformas alcançaram o êxito esperado.

Já sintomática do estado da situação que expunha progressivamente os conflitos com as províncias foi a declaração do conselheiro pernambucano Caetano Maria Lopes Gama, Visconde de Maranguape, em 1855, em um debate no Conselho de Estado por ocasião da discussão de projeto que propunha a ampliação das atribuições do Conselho no que se referia ao Poder Judiciário. Comparando a instituição brasileira com o modelo francês, afirmava:

O Conselho de Estado tornou-se pois juiz privativo de muitas causas, e tribunal de apelação para a imensidade de interesses e direitos privados que se confiaram ao julgamento dos conselhos de prefeituras, compostos de juízes amovíveis e dependentes do governo. É preciso confessar que grandes benefícios colheu então a França do imenso poder do Conselho de Estado. Depois de uma completa anarquia, só a unidade de ação, em todos os ramos da pública administração, pode restabelecer a ordem no Estado, e é por isso que as guerras civis são quase sempre precursoras de ditadura. $\mathrm{O}$ Conselho de Estado prestou então os mais assinalados serviços à França; mas essa necessidade de suas tão desmedidas atribuiçôes devia cessar com a cessação das circunstâncias, que a motivaram (...) É essa jurisdição dos Conselhos de Prefeitura e do Conselho de Estado da França, tão manifestamente contrária ao regime monárquico representativo, adotado naquela nação depois da restauração; é essa tradicional instituição de um governo absoluto, que o projeto nos quer dar. Vejamos se o Brasil pode tolerá-la, e se não provocará a mais justa oposição na Representação Nacional. ${ }^{20}$

Maranguape viu prematuramente os riscos da continuidade da ação do Conselho no sentido da centralização. A justa oposição já se fazia e se tornaria cada vez mais contundente. Anos mais tarde, simultaneamente ao projeto de abolição gradual da escravidão e ao projeto de reorganização do Conselho, em 1867 o conselheiro Pimenta Bueno, Marquês de São Vicente, apresentava à instituição uma proposta de recriação dos conselhos das Presidências das províncias. Na prática, os três projetos se complementavam, representando um amplo programa de reforma, cujo alto teor centralista não escapou à observação dos conselheiros, uma vez que se pretendia que o Conselho de Estado, como segunda instância, servisse também aos conselhos provinciais. 
A ênfase centralizadora foi duramente questionada nas reuniōes ${ }^{21}$. Em geral, por melhores que fossem as intenções, o projeto foi derrotado pelo que de fato representava, um recrudescimento da ação do poder central sobre a política provincial em um momento em que se esperava exatamente o oposto. O Conselho de Estado havia subestimado a força das províncias e as estratégias de negociação, que funcionaram tão bem em momentos de crise e instabilidade política como foram os primeiros anos do Regresso, não mais pareciam suficientes para conter os anseios de mudança. Na prática, tudo indicava que a eficiência na contenção do ritmo das reformas havia conduzido a uma real incapacidade de realizá-las sem lançar mão de dispositivos autoritários. O tempo começava a contar regressivamente para a monarquia e não foi suficiente para que a instituição se recuperasse das críticas de uma oposição que crescia em um ritmo inversamente proporcional, como demonstrariam as crises freqüentes a partir de 1868.

O Conselho procurou assumir uma face bastante diferente daquela que caracterizou o órgão ainda no reinado de Dom Pedro I. Embora mantivesse seu caráter consultivo e não deliberativo, chamou para si a responsabilidade de construção da máquina administrativa do Estado imperial, esclarecendo as dúvidas e definindo atribuições e funções relativas à estrutura burocrática, administrando conflitos de competências, remendando os lapsos, equívocos e contradições que se colocavam pelas lacunas ou necessidade de adaptação da Constituição vigente, considerando-se ainda a sobreposição das emendas constitucionais.

Assim, o Conselho surgira em 1841 como uma forma de controle do Poder Moderador e garantia sua aceitação pelas elites representantes dos diversos grupos que atuavam junto ao poder central, bem como nas províncias, e disso certamente dependia a estabilidade do regime, principalmente nos primeiros anos do Regresso, quando os ânimos ainda se exaltavam e o Império ainda se via ameaçado por revoltas de várias origens e matizes. Já no regimento interno e na lei de criação do órgão aparecia como um de seus objetivos a assessoria ao imperador, e embora o monarca não fosse obrigado pela Constituição a consultá-lo, esperava-se que ele assim o fizesse.

Esse era, na verdade, o ponto nevrálgico da discussão para os chamados liberais, que insistiam em sua oposição quanto à vitaliciedade, quanto ao perigo da perpetuação de uma determinada facção, porque já se previa 
o poder que se lhe destinava, assim como a possibilidade de que extrapolasse suas prerrogativas regimentais, e esses limites foram efetivamente rompidos. Havia, sem dúvida, conflitos; havia contradições e havia superposição de poderes e funções. De fato, sendo vitalício, e estando distante das amarras que eventualmente poderiam representar os partidos, as exigências eleitorais e as audiências públicas da Assembléia Geral, para seus membros o fórum constituído pelo Conselho possibilitava uma maior liberdade de ação, assim como maior liberdade para a defesa de interesses e a proposição e debate de idéias e projetos.

A proposta original sempre fora resguardar o princípio liberal da independência e equilíbrio dos poderes, a partir do qual estes deveriam interagir, mas jamais serem submetidos uns aos outros. Na prática, no entanto, parecia-lhes impossível imaginar uma ordem política sem um poder que se sobrepujasse aos demais; nesse sentido, encontravam todas as vantagens no discurso jurídico, na proposição de que os atos do Poder Moderador não poderiam ser limitados ou julgados pelo Executivo, nem serem responsabilidade do Conselho de Estado, porque o Moderador havia sido concebido como um poder sem limites, como árbitro e fiscal dos demais poderes. Esse bom relacionamento entre o órgão e os gabinetes era eventualmente buscado, mas nem sempre alcançado. Como os novos gabinetes costumavam encontrar certa resistência nas câmaras já instaladas, ao menos quando havia mudança drástica de partido, era comum a solicitação de dissolução da Assembléia. Assim, a organização política conduzia a uma queda de braço quase permanente entre o Executivo e o Legislativo, já que ambos podiam ser dissolvidos pelo Poder Moderador, com a interferência do Conselho que, no entanto, precisava ser oficialmente acionado pelo imperador a pedido do Executivo.

O que se evidenciava progressivamente com mais clareza era uma contradição no próprio texto constitucional no que se referia à responsabilidade pelos atos do Poder Moderador. Nesse objeto específico a carta dava margem a múltiplas interpretaçôes, sempre presentes nas discussōes dos projetos e pareceres apresentados no Conselho ${ }^{22}$. Portanto, o vício encontravase na origem e provocava controvérsias que envolviam diretamente a instituição como agente do Moderador e em suas relações com o Executivo.

A interpretação da Constituição nesse aspecto, naturalmente, sempre esteve condicionada ao cenário político, de forma que em diversos momen- 
tos foi possível advogar o poder absoluto do Moderador sem que tal atitude gerasse maiores conflitos. Entretanto, com o tempo, tais interpretações deixariam o domínio das discussóes jurídicas para assumir uma progressiva identificação partidária que, embora nunca estivesse totalmente ausente, a partir de meados da década de 1860 começava a assumir novas cores, quando as críticas aos excessos do poder pessoal do imperador e a defesa da responsabilidade de seus atos pelo Executivo tornavam-se as bandeiras que auxiliavam na consolidação da identidade política das novas facções e movimentos político-partidários, como o Centro Liberal e o Partido Progressista.

Mas o aconselhamento do Poder Moderador, bem como a delimitação de suas fronteiras em relação ao Executivo, não foi a obra política mais importante do Conselho. Para além desse papel, também estendeu sua atividade reguladora aos demais poderes constitucionais. Assim, em diversos aspectos, surgia como um órgão cuja força se alicerçava também em seu caráter legislador, um papel que se aprimorou e se alargou ao longo do Segundo Reinado, ao sugerir e elaborar projetos de leis, trabalhando diretamente com os gabinetes. O Conselho de Estado encontrava-se ligado ao Parlamento atuando como uma "primeira câmara", no dizer de um dos mais importantes juristas do período, Marquês de São Vicente.

$\mathrm{O}$ exíguo tempo de reunião e funcionamento do Parlamento freqüentemente também serviu como argumento para justificar a incorporação ao Conselho de Estado de uma outra função, a interpretação da lei que, a rigor, deveria ser incumbência do Legislativo ou, conforme o teor da consulta, do Supremo Tribunal de Justiça. A Constituição de 1824 manteve silêncio quanto ao controle da constitucionalidade, anteriormente uma função da Casa da Suplicação, que atuou ainda no período colonial como tribunal supremo de uniformização da interpretação do Direito português. Em princípio, a idéia era aproveitar a experiência francesa, cuja Constituição outorgava ao Poder Legislativo a atribuição de fazer leis, interpretá-las, suspendê-las e revogá-las, bem como velar na guarda da Constituição. Entretanto, embora esse fosse o discurso mais aceito, na prática, a indefinição constitucional abria o caminho para a ação do Conselho, que se tornava progressivamente o órgão interpretativo da lei ${ }^{23}$.

Assim, indubitavelmente era quanto ao Poder Judiciário que a ingerência do Conselho seria mais justamente criticada. A análise das consultas submetidas ao órgão, tanto aquelas que se mantiveram no âmbito das seções 
quanto as que chegaram às conferências do Conselho Pleno, demonstra que esta foi a área onde a interferência da instituição ocorreu de forma mais direta, praticamente ignorando-se a competência do Supremo Tribunal de Justiça ${ }^{24}$.

Na prática, o Conselho esvaziou a ação do Supremo Tribunal, atraindo para sua esfera direta a obra de reorganização do sistema Judiciário no conjunto de medidas ligadas à centralização e consolidação do poder central, relegando-se aquele ao nível de uma instância inferior. Através das consultas que lhe eram submetidas, observa-se que a instituição tornou-se uma espécie de tribunal de recursos nas causas que entendiam como administrativas, assumindo o papel de árbitro nas contendas judiciais, esclarecendo e preenchendo as lacunas da legislação, impondo limites e definindo competências, procurando ainda controlar os desmandos dos desembargadores das Relações. Assim, a instituição desenvolveu uma ampla atuação na área, como já estava previsto em seu regimento interno, justificando a ingerência pela classificação de contencioso administrativo e em diversos momentos chocando-se diretamente com o Poder Judiciário ${ }^{25}$.

\section{0 império das necessidades e a marcha da mudança: o declínio da ação do Conselho}

A obra de centralização iniciada com o Regresso havia encontrado no Conselho de Estado seu mais fiel defensor. Regulando as relaçóes e os limites entre os poderes, discutindo e propondo as leis do Estado, em todas as suas instâncias, a instituição teve um papel fundamental na consolidação do poder central e da monarquia constitucional, procurando sempre conduzir o ritmo das reformas. Como diria Bernardo P. de Vasconcelos,

Eu conheço que nenhuma instituição, em qualquer país, pode ser imutável; todas as instituiçôes humanas estão sujeitas ao império das necessidades. As idéias, os sentimentos e os interesses mudam as instituições; elas devem acomodar-se ao estado social (...) não quero um Conselho de Estado imutável, mas quero se não torne tão amovível que até acoroçoe e instigue o movimento. Eis a conciliação que pretendo conseguir, cujo fim é conciliar a fixura com o movimento, que é natural, que não cabe ao homem evitar (...) as instituiçõos devem ser de tal maneira estabelecidas que, 
sem obstar ao movimento, resistam às inovações rápidas e precipitadas que podem abismar o país $^{26}$.

Entretanto, o político Tavares Bastos, eterno baluarte da causa liberal, mencionou o Conselho quando discutiu as medidas ligadas à autonomia das províncias empreendidas pelo Ato Adicional de 1834, abordando especificamente o papel desta instituição como reguladora das relações entre a província e o poder central e seu papel como um dos principais agentes da centralização:

Instituição alguma, neste Segundo Reinado, há sido mais funesta às liberdades civis e às fraquezas provinciais. Dali Vasconcelos, Paraná e outros estadistas, aliás eminentes, semearam com perseverança as mais atrevidas doutrinas centralizadoras. Fizeram escola, e tudo o que de nobre e grande continham as reformas, perverteu-se ou desapareceu. ${ }^{27}$

Se a conciliação pareceu uma ação eficiente nos primeiros anos após a Maioridade, o discurso obviamente suplantou a prática política do governo. Mesmo a oposição que participava da direção do país através do Conselho, no dizer de Nabuco, excluiu diversos setores emergentes e se amalgamou progressivamente à elite que dava as diretrizes da atuação do Estado. $\mathrm{O}$ acordo que então se obtinha havia priorizado muito menos os projetos de reforma do que a necessidade de manutenção da ordem social e política do país, que procuraram coordenar e controlar através da atuação decisiva do Conselho de Estado.

$\mathrm{Na}$ medida em que se pacificava o Império, essas fraturas surgiam cada vez mais nítidas. Esses impasses e a incapacidade de lidar com as novas conjunturas esvaziaram a ação política do Conselho a partir do terceiro quartel do século. De fato, um novo debate político renascia no final da década de 1860 trazendo de volta à discussão a questão da representação política e a manutenção do poder pessoal do imperador. Do ponto de vista do poder central, o que se observou foi a conclusão do processo de centralização e unificação da monarquia, e as instituições que haviam sido criadas e defendidas para exercer esse papel perdiam paulatinamente sua razão de existir. $\mathrm{O}$ Senado vitalício, o Conselho de Estado e o próprio Poder Moderador começaram a ser violentamente criticados, o que denotava que aquele processo havia efetivamente se esgotado. Os excessos da centralização imobilizavam perigosamente a administração provincial e os anseios de mudanças 
ganharam nova força com o ímpeto reformista da chamada geração de 1870, na qual se destacam Joaquim Nabuco, André Rebouças e Júlio de Castilhos ${ }^{28}$.

Assim, começavam a ser reinterpretadas as relações políticas entre o Conselho, o Poder Executivo e o Moderador, bem como seus laços de dependência e continuidade na consecução da administração pública do Estado $^{29}$. Sofrendo os efeitos dessa conjuntura, o declínio da influência e do poder decisório do Conselho começa a ser percebido já na década de 1870 , momento a partir do qual diminuem sensivelmente o volume de reuniōes e a própria importância e repercussão dos temas ali discutidos. Em diversos sentidos, o crescimento e a consolidação do papel do Poder Executivo se deu diretamente em função do enfraquecimento do Moderador e, conseqüentemente, do próprio Conselho de Estado. Ao final, viam-se forçados a reconhecer que um Executivo forte não poderia seguir eternamente tolhido por instituiçôes que naturalmente se opunham aos preceitos liberais e à própria teoria dos Poderes.

A crise do Conselho é mais nitidamente notada quando seu regimento começou a ser revisto, a partir de proposta elaborada em fins de 1867 pelo Marquês de São Vicente. A crítica ao projeto prendeu-se à intenção que lhe era inerente de ampliação geral do espectro de atuação do Conselho e da conseqüente limitação dos poderes, tanto do Executivo e do Judiciário, quanto da já combalida autonomia provincial. A ampliação do leque de temas a serem submetidos à consulta e, particularmente, a obrigatoriedade da audiência ao Conselho, recebeu franca oposição dos conselheiros, que referiram-se à progressiva transformação do órgão em executor, em detrimento de seu caráter estritamente consultivo. Nesse sentido, a audiência obrigatória corresponderia a uma limitação inconstitucional e desnecessária do Poder Executivo, que usufruía de uma independência que a elite representada no Conselho teoricamente sempre procurou defender ${ }^{30}$.

O Conselho realizaria apenas 32 reuniōes entre 1870 e 1879, boa parte das quais ligadas a questóes emergenciais, como a paz com o Paraguai e a questão religiosa; o número é ainda menor entre 1880 e 1889 e os temas nem de longe lembram a exaustiva atividade da instituição em seu período áureo: embora se mantivessem as solicitações de dissolução da Câmara dos Deputados, incluíram apenas pedidos de crédito suplementar para obras e controle de epidemias, reformas eleitorais e algumas ques- 
tôes internacionais de menor relevância, como a definição de limites com países vizinhos.

Se era o depositário da velha arte de governar, é fato que o Conselho envelhecia junto com a monarquia. Um outro sintoma desse envelhecimento traduzia-se na dificuldade de renovação de seus quadros. O método, a estratégia, não se modificaram e a monarquia continuava a convocar a oposição moderada, mas tudo indicava que já iam longe os tempos em que a nomeação para a instituição representava uma distinção irrecusável. A partir da década de 1870, cinco políticos recusaram oficialmente suas nomeações para a instituição. Esse foi o caso dos baianos Zacarias de Góes e Vasconcelos, em 1870, José Antônio Saraiva, em 1878, e João Maurício Wanderley, Barão de Cotegipe, em 1882, todos presidentes do Conselho de Ministros - que juntos representaram seis dos sete gabinetes não chefiados por conselheiros ao longo do II Reinado. No mesmo ano também não aceitaram a nomeação o político e engenheiro mineiro Cristiano Ottoni e o paulista José Bonifácio Ribeiro de Andrada, o moço. Em 1876 a nomeação foi ainda recusada pelo Visconde de Sinimbu, que só a aceitaria seis anos depois ${ }^{31}$.

O Conselho continuaria, entretanto, a contar com os principais nomes da política imperial, ao menos quando se considera a ocupação de cargos ministeriais. Assim, se o Conselho de Estado, como instituição, começava a perder o controle da máquina política e administrativa do Estado, esta se mantinha solidamente nas mãos das elites ali representadas, elites que, no entanto, deslocavam sua esfera de atuação para outras instâncias de poder ${ }^{32}$.

\section{Conclusão}

A ação do Conselho de Estado colocou em prática um amplo programa de organização da estrutura de governo, conduzido pela elite imperial, que procurou, após o processo de Independência, os caminhos para adequação do Brasil à nova ordem internacional. Nesse caminho, através da interação com os demais poderes, o Conselho contribuiu diretamente para o fortalecimento do modelo monárquico e para a superação das heranças coloniais - permanências de um passado colonial que estava ainda vivamente presente sob diversos aspectos e que permeava as relaçóes 
sociais e políticas, a forma de entender o Estado e as práticas cotidianas de controle político e econômico - , processo para o qual é inegável a influência dos modelos teóricos e práticas liberais.

Também é inegável que o processo de formação do Estado assumiu características próprias, considerando-se principalmente que as elites imperiais tomavam como modelo o Estado-nação europeu. Para alcançá-lo, diferentemente dos antecessores europeus, essas elites não apenas se viram forçadas a reagir às necessidades prementes da política, mas precisaram sobretudo atuar diretamente na consecução de seu objetivo principal de construção da autoridade central. Tal fato, portanto, fez com que no Brasil esse processo se imbuísse de um caráter pragmático e imediatista, visando à consolidação de uma estrutura política que se aproximasse dos padrões internacionais.

Entretanto, a ação em prol da construção de uma identidade para o poder central esbarrou em entraves diversos. Malgrado a proclamada paz que se seguiu ao Regresso, aquela era uma paz relativa, já que os conflitos seguiam latentes. Nesse sentido, a proposição da conciliação pelo gabinete Paraná, em 1853, foi fundamental, e de seu sucesso dependeu a abertura de espaço para algumas reformas. Mas, de perto, no dia-a-dia, a política seguia em plena atividade, por meio de negociações permanentes que se faziam pela inter-relação entre o poder central e poderes locais, entre o público e o privado e entre grupos e instituiçôes, de modo que os sucessivos realinhamentos, cujo caráter aparentemente conjuntural ocultava aquela que era a verdadeira lógica do modelo, terminavam por enfraquecer $o$ mesmo modelo a longo prazo.

Se no plano imediato a ação política traduzia-se em escolhas que, no entanto, nem sempre alcançavam os objetivos almejados, por outro lado, em termos gerais, a política imperial caracterizou-se pela negação do confronto e do conflito, o que impediu a execução das mudanças estruturais necessárias e o enfrentamento direto dos principais problemas que afligiam o país. O Senado não faz política, dizia o conselheiro Nabuco de Araújo, porque ele não deve ser parcial, não deve servir a interesses particulares, não deve interferir no caminho natural da ordem e da liberdade. Não maculem com o pó dos partidos a majestade governativa, exclamava João Manuel Pereira da Silva, acrescentando que a política era ciência experimental e, como tal, aplicava-se às necessidades, e que os estadistas podiam alterar suas opiniōes como os médicos na escolha dos remédios. 
Como ciência, ao menos no nível da ação do Estado, acreditava-se que a política precisava ser pragmática, objetiva. Tratava-se inquestionavelmente de uma postura conservadora, no sentido da manutenção da ordem escravista e de uma hierarquia social excludente. Esse foi o sentido da ação do Conselho de Estado, que se justificava no discurso administrativo por excelência, no ilimitado amparo da Lei, nos esforços de aproximação das dissidências, na prática quase cotidiana de negociação, nas alianças que obedeciam a uma estratégia maior de segurança e estabilidade.

Assim, paradoxalmente, embora alcançassem sucesso na obra de centralização, fundamental no caminho da consolidação de um Estado nacional, este sucesso limitou-se, em geral, à organização e racionalização da estrutura político-administrativa e ao controle dos poderes paralelos, transferindo-se lentamente as funções administrativas para o poder central. Entretanto, a política imperial, pela negação do confronto, não foi capaz de executar uma obra que promovesse uma efetiva publicização das instituições, no sentido de uma real ampliação da participação e representatividade, da superação definitiva de uma prática política baseada nas relações pessoais, ou mesmo a abertura da máquina administrativa. Esse era, de fato, um jogo complexo, onde interesses pessoais ou de grupos moldavam-se a interesses coletivos que se estabeleciam no desenvolvimento de uma ação pública do Estado. A eterna negociação e administração dos conflitos, o permanente adiamento das reformas substanciais, como a abolição da escravidão e a ampliação da representatividade, demonstravam que as permanências características dos tempos iniciais do regime não puderam ser totalmente superadas.

De fato, as contradições pareciam insolúveis. A idéia de representação, mesmo entre liberais históricos, permaneceu razoavelmente inelástica ao longo de todo o período, de forma que o próprio Moderador, uma clara permanência de uma visão da política ainda presa à antiga concepção do papel arbitral e do poder pessoal dos governantes, foi, em geral, aceito por todos, ao menos até a década de 1860, desde que pudesse ser amparado por instâncias como o Conselho de Estado. As conseqüências desse paradoxo traduziam-se ainda pelo predomínio das relaçôes pessoais nas decisões políticas. A política se fazia, então, de forma a conceder espaços ao favorecimento de interesses pessoais, entretanto, tornava-se fundamental a conciliação entre esses espaços e os próprios interesses públicos, 
que começavam a se fazer sentir na medida em que avançava o governo direto, na medida em que o Estado seguia se constituindo como tal, como instância do público, inclusive pela progressiva especialização de funções e atribuiçóes que caracteriza um Estado nacional moderno ${ }^{33}$.

Mas na medida em que a estrutura do Estado se consolidava, colocava-se a questão de que se o Executivo era o responsável pelas ações da monarquia, se era consenso que os poderes constitucionais eram soberanos e independentes, se o Judiciário reformado devia ter autonomia, se o Legislativo era o lugar da legítima representação, qual seria, então, nesse contexto, o papel do Poder Moderador e de seu principal agente, o Conselho de Estado? Como poderia ser mantido um sistema monárquico que se construíra sobre essas instituiçôes? Nesse sentido, o próprio processo que se orientava no sentido da formação e consolidação do Estado tornava obsoletas as instituiçōes que o formularam.

Nesse processo o Conselho tornou-se um instrumento fundamental. A instituição de fato traduzia os anseios, confrontos e contradições daquela sociedade, a sociedade possível no Brasil do século XIX, considerando-se principalmente a baixa representatividade eleitoral. O Conselho de Estado, como instância de poder, não escapou a essas circunstâncias, tornando-se palco do acirramento dos conflitos existentes, ao mesmo tempo em que se consolidava seu papel na administração.

É exatamente essa dimensão que é revelada quando se acrescenta à análise intrínseca do funcionamento da máquina burocrática e das instituiçôes governamentais o estudo dos indivíduos e dos projetos coletivos que davam movimento à estrutura política. Ao serem consideradas suas relações permanentes e cotidianas com a sociedade, suas redes de aliança, suas estratégias de negociação e perpetuação no poder, é possível apontar os reais objetivos e a lógica que norteava a ação daqueles que elaboravam e geriam as políticas públicas.

A investigação e a análise das redes de relações permite, assim, extrapolar os limites da Corte como espaço exclusivo do poder imperial. Sob esse aspecto, cabe lembrar que o processo político em nível regional não se desenvolvia como um simples reflexo da política central, mas apresentava uma história e uma dinâmica próprias, que tinham raízes mais remotas no período colonial e eram influenciadas diretamente por suas especificidades e pelas diferentes conjunturas locais. Também nesse âmbi- 
to as relações entre grupos, famílias e facções políticas tinham de ser refeitas e mantidas permanentemente.

Tais aspectos demonstram ainda que o grupo que chegou à cúpula da administração imperial não era um grupo homogêneo, que teria assumido o Estado e do centro do poder dava execução a um projeto político fechado. As elites encontravam-se, efetivamente, unidas por suas amplas teias de relacionamentos que, como tal, reuniam múltiplos interesses, agindo em função de circunstâncias específicas, desenvolvendo estratégias para manter os recursos econômicos, sociais e políticos das redes a que pertenciam, bem como suas relações com o poder tanto no nível central, quanto nos diferentes níveis regionais.

Portanto, a centralização e, conseqüentemente, o próprio processo de formação do Estado não podem ser vistos como um fenômeno de única direção, imposto do centro para a periferia, partindo da ação e interesses de uma determinada classe ou grupo específico - sejam esses interesses econômicos ou políticos, sejam esses grupos saquaremas ou burocratas, estadistas ou fazendeiros - , que dominou o centro de poder e dali planejou a união do Império e a unificação territorial do país.

Ao contrário, é preciso indagar, em relação aos diversos segmentos dessa elite, aos quais interessara sempre a manutenção da ordem e da hierarquia social, o que os conduziu a participar ativamente desse processo, procurando se fazer representar na cúpula dirigente do Estado. Isso só foi possível graças à continuidade das suas redes de relações e o desenvolvimento de estratégias permanentes de controle dos interesses e conflitos internos às elites, mediante o estabelecimento de práticas e lócus de intermediação que se concretizaram na criação de cargos e instituições específicas - como o próprio Conselho de Estado - , as quais precisavam se renovar constantemente ao longo do período.

Os indivíduos reunidos no Conselho de Estado detiveram efetivamente o poder de decisão sobre os destinos do país e o exerceram através das principais instituições governamentais. Se essa atuação nem sempre foi vitoriosa, ou se por vezes não foi capaz de evitar ou controlar os conflitos, de qualquer forma seguia garantida a reprodução da estrutura de poder que referendava e legitimava as açóes do governo.

Mas, por outro lado, cabe ressaltar que a consideração da importância política das redes de relacionamento não significa que essa ação possa 
se resumir na imposição de práticas clientelares e de troca de favores e nem estas práticas podem ser entendidas como determinantes do tipo de Estado e sociedade que se constituiu no período. É preciso considerar toda a complexidade do jogo político quando se olha não exclusivamente do centro, mas a partir das diferentes regiōes; quando se contempla não apenas a ação do Estado e suas instituições, mas o papel desempenhado pelos indivíduos e suas redes de relações, suas estratégias de negociação, suas crenças, idéias e tradições; quando se observa não apenas a política em seu nível macro, mas também as pequenas açōes cotidianas que vão dando forma e consolidando a extensão do poder central.

Partindo-se do pressuposto de que elites podem ser identificadas como tal, porque têm sempre como objetivo assim se manterem, controlando ao máximo o capital, seja ele político, econômico, social, elas necessitam desenvolver estratégias e estarem atentas para fazerem as alianças mais convenientes a esse fim, e essa conveniência flutua de acordo com as conjunturas. O exercício da política significava, assim, uma dinâmica permanente de estratégias de manutenção da hierarquia, de suas fortunas, seus cargos e seu status e influência social. A complexidade crescente da política que se desenvolve ao longo do período imperial, com as reformas administrativas, as definições e organizações de funções e atribuições dos cargos, colocava novos impasses a essa cultura, na medida em que começavam a se firmar as idéias abolicionistas e o ideário republicano que, por meio do questionamento das bases do sistema, selaram o fim da monarquia constitucional.

A obra do Conselho, sua ação normativa da administração e da Justiça, formativa das instituiçôes públicas e centralizadora do poder assumiu um papel fundamental na construção de uma identidade política para o Estado brasileiro que garantiu a estabilidade da monarquia de Pedro II por quase meio século. Nesse sentido, as discussões acerca da abolição da escravidão, a reforma eleitoral e os caminhos do país na guerra do Paraguai importavam tanto quanto os crimes do juiz de Direito no interior da província, a aposentadoria de um velho coronel ou as últimas esperanças de um réu escravo condenado pela morte de seu senhor. $\mathrm{O}$ que então se colocava era a direção de sua ação, o volume, a extensão e o conjunto de sua obra, que buscou o reforço da autoridade central, o controle da vida política e a manutenção da ordem e das hierarquias no país. 
Por sua composição, sua posição na estrutura governamental, seu papel regulador e pela repercussão de seus atos, o voto no Conselho era, antes de tudo, um voto essencialmente político, malgrado a dimensão, a natureza ou a importância das questôes que discutiu, porque a política, naturalmente, se fazia não apenas nos debates acerca das bases em que se assentava o modelo social, econômico e político-administrativo brasileiro. Ela estava presente também, cotidianamente, nas micro-relações, nos detalhes, nas ações normativas regulares empreendidas em diferenciadas esferas de poder.

O Conselho representou, portanto, o grande instrumento da conciliação, entendida não apenas como a necessidade de superação de diferenças partidárias, por mais sinceras que fossem essas divergências, mas, no sentido que assumiu para a instituição, representava a busca de equilíbrio entre a tradição e o moderno, entre a fixura e o movimento. Conciliação e movimento - no sentido da resistência provincial e da ânsia de reformas - pareciam as palavras de ordem da nova situação política inaugurada com o Regresso. O Conselho de Estado não se manteve imutável mas, como instância de representação dos interesses, temores e conflitos das elites nacionais, soube administrar as diferenças internas e controlar, certamente com excessiva eficiência, o movimento; o império das necessidades de que falava Vasconcelos também realizou sua obra, retardando as reformas e administrando, através de suas atrevidas doutrinas, a marcha das mudanças.

\section{Notas}

${ }^{1}$ Segundo Paula Sousa, Devemos reconhecer que os principios dominantes no pais, desde que começou a nossa revolução, são dois: monarquia e liberdade. Monarquia sem liberdade é escravidão para nós, não se pode merecer os respeitos e simpatias da nação. A nação tem ligado estas duas idéias; é o que ela deseja; é por isso que se tem sacrificado há tantos anos. Apud José Honório Rodrigues. Conselho de Estado: O quinto poder? Brasília: Senado Federal, 1978. p. 156.

${ }^{2}$ José Subtil. “Os poderes do Centro”. In José Mattoso (dir.). História de Portugal. Lisboa: Estampa, 1998. v.4, O Antigo Regime (1629-1807).

${ }^{3} \mathrm{O}$ termo elite está sendo utilizado em seu sentido amplo, de forma a abarcar aqueles que se encontram no topo da hierarquia social. Neste sentido, segundo J Scott, surge como 
uma vasta zona de investigação cientifica cobrindo profissionais da política, empresários, legisladores, etc., e não evoca nenhuma implicação teórica particular, ou seja, a minoria dispondo, em uma sociedade determinada, em um dado momento, de privilégios decorrentes de qualidades naturais valorizadas socialmente ou de qualidades adquiridas (...) No plural, a palavra "elites" qualifica todos aqueles que compoem o grupo minoritário que ocupa a parte superior da hierarquia social e que se arrogam, em virtude de sua origem, de seus méritos, de sua cultura ou de sua riqueza, o direito de dirigir e negociar as questóes de interesse da coletividade. John Scott. Les élites dans la sociologie anglo-saxonne. In Ezra Suleman e Henri Mendras. Le recrutement des élites en Europe. Paris: Editions la Découverte, 1995, p.9. e Giovanni Busino. Elites et élitisme. Paris: Presses Universitaires de France, 1992.

${ }^{4}$ Antônio Manuel Hespanha. Poder e Instituições no Antigo Regime. Guia de Estudo. Lisboa: Cosmos, 1992. Cadernos Penélope, p.11-22.

5 Segundo M. Gribaudi, a noção de rede social é entendida como a representação das interaçôes contínuas das diferentes estratégias individuais. Ver Henrique E. Lima. Microhistória: escalas, indícios e singularidades. Campinas, 1999. Tese (Doutorado em História). Universidade Estadual de Campinas. mimeo., p. 21.

${ }^{6}$ Angela Xavier e A. M. Hespanha. "As Redes Clientelares". In José Mattoso (dir.) História de Portugal. Lisboa: Estampa, 1998, v.4, p. 339.

${ }^{7}$ Idem, p. 347.

${ }^{8}$ Tais crenças correspondem a uma cultura política, entendida no sentido do conjunto de valores, comportamentos e formas de conceber a organização político-administrativa, resultado de um longo e dinâmico movimento de interaçōes e acumulação de conhecimentos e práticas. Jacques Lagroye. Sociologie Politique. Paris: Dalloz, 1991, p.369. Ver também Serge Bernstein. "A cultura política”. In: JP Rioux e JF Sirinelli (dir.). Para uma História Cultural. Lisboa: Editorial Estampa, 1998.

${ }^{9}$ O Conselho de Estado contou, ao longo do período, com 72 conselheiros. Dados levantados em Tavares de Lyra. Instituiçôes Políticas do Império. Brasília: Senado Federal, 1978; A. E. Taunay. O Senado do Império. Brasília: Senado Federal, 1972; A.S. Sisson. Galeria dos Brasileiros Ilustres. Brasília: Senado Federal, 1999. 2v e Almanaque Laemmert: administrativo, mercantil e industrial da Corte e da provincia do Rio de Janeiro, 1859- Província, 1844-1889. In: wwwcrl.uchicago.edu.

${ }^{10} \mathrm{O}$ período da Conciliação, entendido como a política iniciada no Gabinete Paraná (1853-1856), busca continuidade nos gabinetes conservadores seguintes ao menos até 1862; a partir de então, ainda seria empreendida pela liga progressista (1862-1868), comandada por gabinetes liberais. Francisco Iglesias, Prefácio. In: José Honório Rodrigues (org.). Atas do Conselho de Estado. Brasília: Senado Federal, 1973-1978. v.6, p.IX-XV.

${ }^{11} \mathrm{O}$ mesmo ocorreria com o Senado, onde se esperava que o imperador escolhesse os candidatos do partido que estava no poder, o que freqüentemente ocorreu. Ver Beatriz Cerqueira Leite. O Senado nos anos finais do Império, 1870-1880. Brasília: Senado Federal; Universidade de Brasília, 1978, v. 2. p. 33 e 72.

${ }^{12}$ Beatriz Cerqueira Leite. Op. cit., p. 103-4. 
${ }^{13}$ Os dados referidos encontram-se principalmente no Almanaque Laemmert, correspondências pessoais, textos biográficos, verbas testamentárias, inventários e testamentos, complementados por informações esparsas encontradas nas obras citadas de J. Needell, J. Nabuco, Tavares de Lyra e dicionários biográficos. Sobre as redes no Conselho de Estado, ver Maria Fernanda V. Martins, A velha arte de governar: um estudo sobre politica e elites a partir do Conselho de Estado (1842-1889). Rio de Janeiro, 2005. Tese (Doutorado em História). Universidade Federal do Rio de Janeiro. mimeo., cap. III.

${ }^{14}$ Para efeito de análise, priorizaram-se as atividades das seções dos Negócios do Império e da Justiça, principalmente em função do elevado volume de questões a elas submetidos.

${ }^{15}$ Para se ter uma idéia do volume de questões ali decididas, o livro de protocolo da Seção dos Negócios da Justiça entre 1861 e 1862 registrou um total de 156 consultas, das quais apenas duas foram encaminhadas ao Conselho Pleno. Desse total, cerca de $60 \%$ referiamse a recursos de graça e a análises das leis provinciais. As demais relacionavam-se a recursos de particulares, aposentadorias, denúncias de improbidade administrativa, dúvidas legais etc.. ANRJ. Livro de protocolo da Seção dos Negócios da Justiça. Códice 303, v. 1.

${ }^{16}$ Para citar exemplos, a Seção do Império registrou 104 consultas entre 1845 e 1847, das quais apenas uma chegou ao Conselho Pleno. Destas, cerca de $32 \%$ referiam-se à análise de atos legislativos das assembléias provinciais, e aproximadamente $30 \%$ a questôes eleitorais, a maioria das quais relativas às dúvidas encaminhadas pelas autoridades locais acerca da nova lei eleitoral, promulgada em 1846. ANRJ. Registro de Pareceres do Conselho de Estado, Seção dos Negócios do Império. códice 49, v. 3. Da mesma forma, segundo o relatório ministerial de 1858, em apenas um ano, entre 1858 e 1859, a Seção elaborou 151 pareceres, sendo 28 sobre questôes eleitorais, 22 sobre leis provinciais, 34 sobre incorporações de companhias e aprovações de estatutos, 15 acerca de privilégios e 52 sobre diferentes objetos. BRASIL. Relatório apresentado... pelo ministro e secretário de Estado dos Negócios do Império Sergio Teixeira de Macedo. Rio de Janeiro: Tipografia Universal de Laemmert, 1859, Anexo C.

${ }^{17}$ BRASIL. Relatório apresentado ... pelo ministro e secretário de estado dos Negócios da Agricultura, Comércio e Obras Públicas, dr. Jesuíno Marcondes de Oliveira e Sá. Rio de Janeiro: Tipografia Universal de Laemmert, 1865. Anexo A, p.1-64. A análise dos estatutos baseava-se no código comercial de 1850, que havia extinguido a Real Junta do Comércio, Agricultura, Fábricas e Navegação, criada em 1808. Assim, sua antiga função, na medida em que envolvia solicitações de privilégios, garantias de juros especiais, dotações orçamentárias ou benefícios proporcionados por leis específicas, como a concessão de sesmarias para instalação de colônias agrícolas, terminou por recair sobre o Conselho de Estado. Ver Ives Gandra M. Filho. "Evolução Histórica da Estrutura Judiciária Brasileira”. Revista Jurídica Virtual, no 5, setembro de 1999. In: http://www.presidencia.gov.br/ ccivil_03/revista/Rev_05/evol_historica.htm.

18 José Murilo de Carvalho. Teatro de sombras: a politica imperial. Rio de Janeiro/ São Paulo: IUPERJ/ Vértice, 1988. p.109.

${ }^{19}$ BRASIL. Relatório apresentado... pelo ministro e secretário de Estado dos Negócios do Império Paulino José Soares de Sousa. Rio de Janeiro: Tipografia Universal de Laemmert, 1868. 
${ }^{20}$ Ata de 28 de abril de 1855. In: José Honório Rodrigues (org.). Atas do Conselho de Estado. Brasília: Senado Federal, 1973-1978. v. 4, p. 281-282.

${ }^{21}$ A esse respeito declarava ainda o conselheiro Bernardo de Sousa Franco: Não se limita porém o projeto à criação de conselhos consultivos: converte-os em deliberativos na decisão dos recursos (...) E no projeto de reforma do Conselho de Estado ainda cria uma Segunda instância de apelação. É levar muito longe a centralização administrativa! (...) Estamos governados demais e não de menos. Ata de 14 de novembro de 1867. José H. Rodrigues (org.). Atas do Conselho de Estado. Brasília: Senado Federal, 1973-1978. v. 7, p. 116-117.

${ }^{22}$ Essas contradições foram assinaladas com muita propriedade por Sergio B. de Holanda: A própria carta constitucional do Império já oferece problemas embaraçosos, cuja solução se presta a infindáveis controvérsias. De conformidade com o artigo 102, para citar um exemplo, o imperador é o chefe do Poder Executivo e o exerce através de seus ministros de Estado. Mas o artigo 99 declara que a pessoa do imperador é inviolável e sagrada, não se sujeitando a responsabilidade alguma. A dificuldade de dissociar de uma ação, com todas as suas conseqüências, aquele que a exerce legalmente, tentariam alguns resolvê-la pretendendo que, a chefia seria puramente honorífica, e então toda iniciativa cabe aos agentes que, assim, justamente, podem responder por elas (...) Houve também quem tentasse superar o obstáculo julgando que o chefe apenas preside, inspeciona ou fiscaliza os ministros quando agem em seu nome, mas aqui já se introduz um non sequitur. Outros finalmente entendem que o imperador, ainda que irresponsável, também decide, envolvendo-se no governo ativo, e épreciso confessar que nada se opõe na carta de 24 a este modo de ver. Sergio Buarque de Hollanda. "O Brasil Monárquico do Império à República”. In: Sergio Buarque de Hollanda (org.) História Geral da Civilização Brasileira. Rio de Janeiro: Bertrand Brasil, 2004. v. 5, p. 69.

${ }^{23}$ Ives Gandra M. Filho. Op. cit.

${ }^{24}$ Constituído em 1829, o tribunal viria substituir a Mesa do Desembargo do Paço e da Consciência e Ordens, criada em 1808 como instância superior de Justiça. Indiretamente, visava controlar o caos reinante na estrutura jurídica que se desenvolvera ainda no período colonial. Tavares de Lyra. Op. cit., p. 153-161.

${ }^{25}$ Segundo T. Lyra, Não parou na lei que restaura o conselho e em seu regimento esse cerceamento de atribuiçôes, que, acentuado em leis e regulamentos posteriores, transformou $o$ contencioso administrativo numa modalidade nova - absorvente e inconstitucional — da Justiça (...) de tal modo que, em muitos casos de recursos, a audiência do conselho passou, legalmente, de facultativa à obrigatória. Tavares de Lyra. Op. cit., p. 142-3.

${ }^{26}$ Apud José H Rodrigues. Conselho de Estado: O quinto poder. Brasília: Senado Federal, 1978 , p.160.

${ }_{27}$ Apud Gabriela N. Ferreira. Centralização e Descentralização no Império: o debate entre Tavares Bastos e o Visconde de Uruguai. São Paulo: Ed. 34, 1999. p. 114.

${ }^{28}$ Ver Sergio Buarque de Hollanda. Op. cit., e Beatriz de Cerqueira Leite. Op. cit., Introdução e p. 16. Sobre o movimento intelectual dos anos de 1870, ver Angela Alonso. Idéias em movimento: a geração 1870 na crise do Brasil-Império. São Paulo: Paz e Terra, 2002. p. 331. 
${ }^{29}$ Reforçando essa idéia, quando da formação da liga progressista em 1864, em princípio uma tentativa de fazer renascer o espírito da conciliação, e após o sucesso por ela alcançado nas eleições daquele ano, Nabuco de Araújo, dois anos antes de ser nomeado para o Conselho de Estado, declarava no programa do partido progressista que este tinha como máxima sagrada a responsabilidade dos ministros de Estado pelos atos do Poder Moderador. Joaquim Nabuco. Um Estadista no Império. Rio de Janeiro: Topbooks, 1997. p. 452.

${ }^{30}$ Atas de 6, 13 e 27 de fevereiro; de 5, 12, 19 e 26 de março e de 2 de abril de 1868. José Honório Rodrigues (org.). Atas do Conselho de Estado. Brasília: Senado Federal, 1973-1978. v. 7. ${ }^{31}$ Tal quadro também se verificava na escolha dos presidentes do Conselho de Ministros, para o qual as recusas se tornavam freqüentes, particularmente na década de 1880 . Ver Sergio Buarque de Hollanda. O Brasil Monárquico: do Império à República. In: Sergio Buarque de Hollanda. Op. cit., p.354-355.

${ }^{32}$ Quanto aos 13 gabinetes organizados entre 1870 e 1882, nove foram presididos por membros do Conselho de Estado, sendo que cerca de 32\% das pastas ministeriais no mesmo período encontravam-se ainda controladas por conselheiros. Barão de Javari. Organizaçôes e Programas Ministeriais. Rio de Janeiro: Departamento de Imprensa Nacional, 1962. p. 251-257.

${ }^{33}$ Ver Charles Tilly. Coerção, capital e estados europeus. 1990-1992. São Paulo: EDUSP, 1996. p. 118-20.

\section{Referências bibliográficas}

ALMANAQUE Laemmert. administrativo, mercantil e industrial da Corte e da província do Rio de Janeiro, 1859 - Província, 1844-1889. In: wwwcrl.uchicago.edu.

ALONSO, Angela. Idéias em movimento: a geração 1870 na crise do Brasil-Império. São Paulo: Paz e Terra, 2002.

ANRJ. Livro de protocolo da Seção dos Negócios da Justiça. códice 303, v. 1.

ANRJ. Registro de Pareceres do Conselho de Estado, Seção dos Negócios do Império. Códice 49, v. 3.

BERNSTEIN, Serge. "A cultura política”. In: Jean-Pierre Rioux e Jean-François Sirinelli (dir.). Para uma História Cultural. Lisboa: Editorial Estampa, 1998

BOBBIO, Norberto \& BOVERO, Michelangelo. Sociedade e Estado na Filosofia Política Moderna. São Paulo: Brasiliense, 1987.

BRASIL. Relatório apresentado à Assembléia Geral Legislativa pelo ministro e secretário de Estado dos Negócios do Império, Sergio Teixeira de Macedo. Rio de Janeiro: Tipografia Universal de Laemmert, 1859, Anexo C.

BRASIL. Relatório apresentado à Assembléia Geral Legislativa pelo ministro e secretário de Estado dos Negócios do Império, Paulino José Soares de Sousa. Rio de Janeiro: Tipografia Universal de Laemmert, 1868. 
BRASIL. Relatório apresentado à Assembléia Geral Legislativa pelo ministro e secretário de estado dos Negócios da Agricultura, Comércio e Obras Públicas dr. Jesuíno Marcondes de Oliveira e Sá. Rio de Janeiro: Tipografia Universal de Laemmert, 1865.

BUARQUE DE HOLLANDA, Sergio. "O Brasil Monárquico do Império à República”. In: Sergio Buarque de Holanda (org.) História Geral da Civilização Brasileira. Rio de Janeiro: Bertrand Brasil, 2004. v. 5.

BURGUIERE, André (org.). Dicionário das ciências históricas. Rio de Janeiro: Imago, 1993.

BUSINO, Giovanni. Elites et élitisme. Paris: Presses Universitaires de France, 1992.

CARVALHO, José Murilo de. Teatro de sombras: a política imperial. Rio de Janeiro/ São Paulo: IUPERJ/ Vértice, 1988.

ELIAS, Norbert. Processes of State formation and Nation building. In Transactions of the 7th World Congress of Sociology 1970, vol.3. Sofia: ISA, 1972, p. 274-84. FERREIRA, Gabriela Nunes. Centralização e Descentralização no Império: o debate entre Tavares Bastos e o Visconde de Uruguai. São Paulo: Ed. 34, 1999.

FERREIRA, Marieta de Moraes. "A nova 'velha história': o retorno da história política”. Estudos Históricos, Rio de Janeiro, vol. 5, n. 10, 1992, p. 265-271.

GRAHAM, Richard. Clientelismo e política no Brasil do século XIX. Rio de Janeiro: Editora UFRJ, 1997.

HESPANHA, Antônio Manuel. Poder e Instituiçôes no Antigo Regime. Guia de Estudo. Lisboa: Cosmos, 1992. Cadernos Penélope, p.11-22.

JAVARI, Barão de. Organizaçôes e Programas Ministeriais. Rio de Janeiro: Departamento de Imprensa Nacional, 1962.

LAGROYE, Jacques. Sociologie Politique. Paris: Dalloz, 1991.

LEITE, Beatriz Cerqueira. O Senado nos anos finais do Império, 1870-1880. Brasília: Senado Federal; Universidade de Brasília, 1978.

LEVI, Giovanni. A herança imaterial: trajetória de um exorcista no Piemonte do século XVII. Rio de Janeiro: Civilização Brasileira, 2000.

LIMA, Henrique Espada. Microhistória: escalas, indícios e singularidades. Campinas, 1999. Tese (Doutorado em História). Universidade Estadual de Campinas. mimeo.

LYRA, Augusto Tavares de. Instituiçôes Políticas do Império. Brasília: Senado Federal, 1978 
MARTINS FILHO, Ives Gandra. "Evolução Histórica da Estrutura Judiciária Brasileira”. Revista Jurídica Virtual, no 5, setembro de 1999. In: http:// www.presidencia.gov.br/ccivil_03/Revista/Rev_05/ evol_historica.htm.

MARTINS, Maria Fernanda. A velha arte de governar: um estudo sobre politica e elites a partir do Conselho de Estado (1842-1889). Rio de Janeiro, 2005. Tese (Doutorado em História). Universidade Federal do Rio de Janeiro. mimeo.

NABUCO, Joaquim. Um estadista no Império. Rio de Janeiro: Topbooks, 1997. $2 \mathrm{v}$.

NEEDELL, Jeffrey D. Belle Époque Tropical: Sociedade e cultura de elite no Rio de Janeiro na virada do século. São Paulo: Companhia das Letras, 1993.

PUJOL, Xavier Gil. "Centralismo e Localismo? Sobre as relações políticas e culturais entre capital e territórios nas monarquias européias dos séculos XVI e XVII". Penélope, n. 6, 1991

RODRIGUES, José Honório (org.). Atas do Conselho de Estado. Brasília: Senado Federal, 1973-1978. 13v.

RODRIGUES, José Honório. O Conselho de Estado: o quinto poder? Brasília: Senado Federal, 1978.

SIMŌES NETO, Teotônio. Os Bacharéis na politica e a politica dos bacharéis. São Paulo, 1983. Tese (Doutorado em História). Universidade de São Paulo. mimeo. $2 \mathrm{v}$

SISSON, A.S. Galeria dos Brasileiros Ilustres. Brasília: Senado Federal, 1999. $2 \mathrm{v}$.

SUBTIL, José. “Os poderes do Centro”. In José Mattoso (dir.) História de Portugal. Lisboa: Estampa, 1998, v.4, O Antigo Regime (1629-1807).

SULEIMAN, Ezra e MENDRAS, Henri. Le recrutement des élites en Europe. Paris: Editions la Découverte, 1995.

TAUNAY, Affonso de E. O Senado do Império. Brasília: Senado Federal, 1972. TILLY, Charles. Coerção, capital e estados europeus. 1990-1992. São Paulo: EDUSP, 1996.

VEIGA, José Xavier da. Efemérides Mineiras. Belo Horizonte: Centro de Estudos Históricos e Culturais. Fundação João Pinheiro, 1998. 4v.

XAVIER, Angela Barreto e HESPANHA, Antônio Manuel. "As Redes Clientelares”. In José Mattoso (dir.) História de Portugal. Lisboa: Estampa, 1998, v.4, O Antigo Regime (1629-1807), A Arquitetura dos Poderes. 


\section{Resumo}

Esse artigo aborda as relaçōes de poder que se estabeleceram entre as elites ao longo do periodo imperial, com base na análise do grupo reunido no segundo Conselho de Estado (1842-1889), instituição que atuou como um corpo de conselheiros criado após a declaração da maioridade do imperador Pedro II para apoiar a monarquia constitucional e auxiliar sua ação governamental. Foram investigadas as origens e as práticas institucionais do Conselho de Estado, as bases em que se assentava sua ação politica, bem como os esforços de seus integrantes em conciliar as heranças representadas pela estrutura de mando colonial, a influência portuguesa de uma antiga concepção da política e da administração e as novas demandas trazidas pelo ideário liberal. Através da instituição procurou-se investigar a participação das elites brasileiras no Estado no século XIX a partir da reconstituição das trajetórias individuais dos conselheiros e de suas redes de relaçôes políticas e sociais. Essa investigação é complementada com a análise das estratégias de alianças e negociação que se estabeleceram entre os mesmos conselheiros e os setores dominantes do pais ao longo do segundo Reinado. Palavras-chave: Elites, Estado imperial, Conselho de Estado, Redes de relaçôes.

\section{Abstract}

This article studies power relations in the Brazilian imperial State based on an analysis of the elite that came together in the second State Council (1842-1889). The council acted as a body of councilors created after the declaration of emperor Peter II's majority and as an instrument of support to the monarchy and the exercise of its function. Were examined the origins and institutional practices of the State Council, the bases on which its political actions rested, as well as the efforts of its members in conciliating a heritage represented by the structure of a prior colonial authority, the Portuguese influence of an old administrative and political conception, and the new demands brought about by a liberal set of ideas. Through this council, this thesis investigated the Brazilian elite's State participation in the $19^{\text {th }}$ century based on the reconstitution of the councilors' individual trajectories as well as the networks of their political and social relations. This investigation is complemented with an analysis of alliance and negotiation strategies that were established between these same councilors and the dominant sectors of the country during the "Segundo Reinado".

Key-words: Elites, Imperial State, State Council, Networks. 